\title{
The birth of the Alps: Ediacaran to Paleozoic accretionary processes and crustal growth along the northern Gondwana margin
}

\author{
S. Siegesmund ${ }^{1} \cdot$ S. Oriolo ${ }^{2}$ (]) B. Schulz ${ }^{3} \cdot$ T. Heinrichs $^{1} \cdot$ M. A. S. Basei ${ }^{4} \cdot$ B. Lammerer $^{5}$
}

Received: 9 December 2020 / Accepted: 1 March 2021 / Published online: 10 May 2021

(c) The Author(s) 2021

\begin{abstract}
New whole-rock geochemical and coupled U-Pb and Lu-Hf LA-ICP-MS zircon data of metasedimentary rocks of the Austroalpine, South Alpine and Penninic basement domains are presented, to disentangle the pre-Variscan tectonic evolution of the proto-Alps. The studied units seem to record distinct stages of protracted Late Ediacaran to Carboniferous tectonosedimentary processes prior to the Variscan collision. In the case of Austroalpine and South Alpine units, nevertheless, no major differences in terms of provenance are observed, since most detrital zircon samples are characterized by a major Pan-African peak. Their detrital zircon spectra record a provenance from the northeastern Saharan Metacraton and the Sinai basement at the northern Arabian-Nubian Shield, being thus located along the eastern Early Paleozoic northern Gondwana margin, whereas sources located further west are inferred for the Penninic Unit, which might have been placed close to the Moldanubian Unit of the Bohemian Massif. In any case, it is thus clear that the Alpine basement remained in a close position to the Gondwana mainland at least during the Early Paleozoic. The Late Ediacaran to Silurian tectonic evolution, which includes Cadomian and Cenerian tectonometamorphic and magmatic processes, seem thus to record a continuum related to a retreating-mode accretionary orogen, with diachronous back-arc basin opening and possibly discrete compressional/ transpressional pulses linked to changes in subduction zone dynamics. On the other hand, it is inferred that the Alpine basement essentially comprises Pan-African metasedimentary and subordinate metaigneous rocks, possibly with very few Early Neoproterozoic relics. This basement was significantly reworked during the protracted Paleozoic orogenic evolution, due to anatexis and/or assimilation by mantle-derived juvenile magmatism.
\end{abstract}

Keywords Alpine basement $\cdot$ Cadomian orogeny $\cdot$ Cenerian orogeny $\cdot$ Retreating-mode accretionary orogen $\cdot$ Sedimentary provenance $\cdot$ Detrital zircons

S. Oriolo

seba.oriolo@gmail.com; soriolo@gl.fcen.uba.ar

1 Geoscience Centre, Georg-August-Universität Göttingen, Goldschmidtstraße 3, 37077 Göttingen, Germany

2 CONICET-Universidad de Buenos Aires, Instituto de Geociencias Básicas, Aplicadas y Ambientales de Buenos Aires (IGEBA), Intendente Güiraldes 2160, C1428EHA Buenos Aires, Argentina

3 Division of Economic Geology and Petrology, Institute of Mineralogy, TU Bergakademie Freiberg, Brennhausgasse 14, 09596 Freiberg/Saxony, Germany

4 Centro de Pesquisas Geocronologicas, Instituto de Geociências, Universidade de São Paulo, Rua do Lago 562, São Paulo CEP 05508-080, Brazil

5 Department of Earth and Environomental Sciences, Ludwig-Maximilians-Universität München, Luisenstraße 37, 80333 Munich, Germany

\section{Introduction}

Convergent margins are the locus of accretionary orogens, which can be divided into advancing and retreating types depending on whether they undergo crustal thickening or thinning, respectively (Cawood et al. 2009). Net crustal growth, which results from the positive balance between crustal loss, recycling and addition processes, commonly occurs along accretionary orogens due to the presence of both in situ and ex situ mechanisms of juvenile crust generation (Collins 2002; Cawood et al. 2009; Clift et al. 2009; Scholl and von Huene 2009; Stern and Scholl 2010; Collins et al. 2011; Stern 2011; Cochrane et al. 2014). In situ mechanisms imply mantle-derived magma emplacement in the arc/back-arc regions, whereas ex-situ processes are related to the generation of oceanic crust (e.g., island arcs, seamounts, among others), which are ultimately accreted 

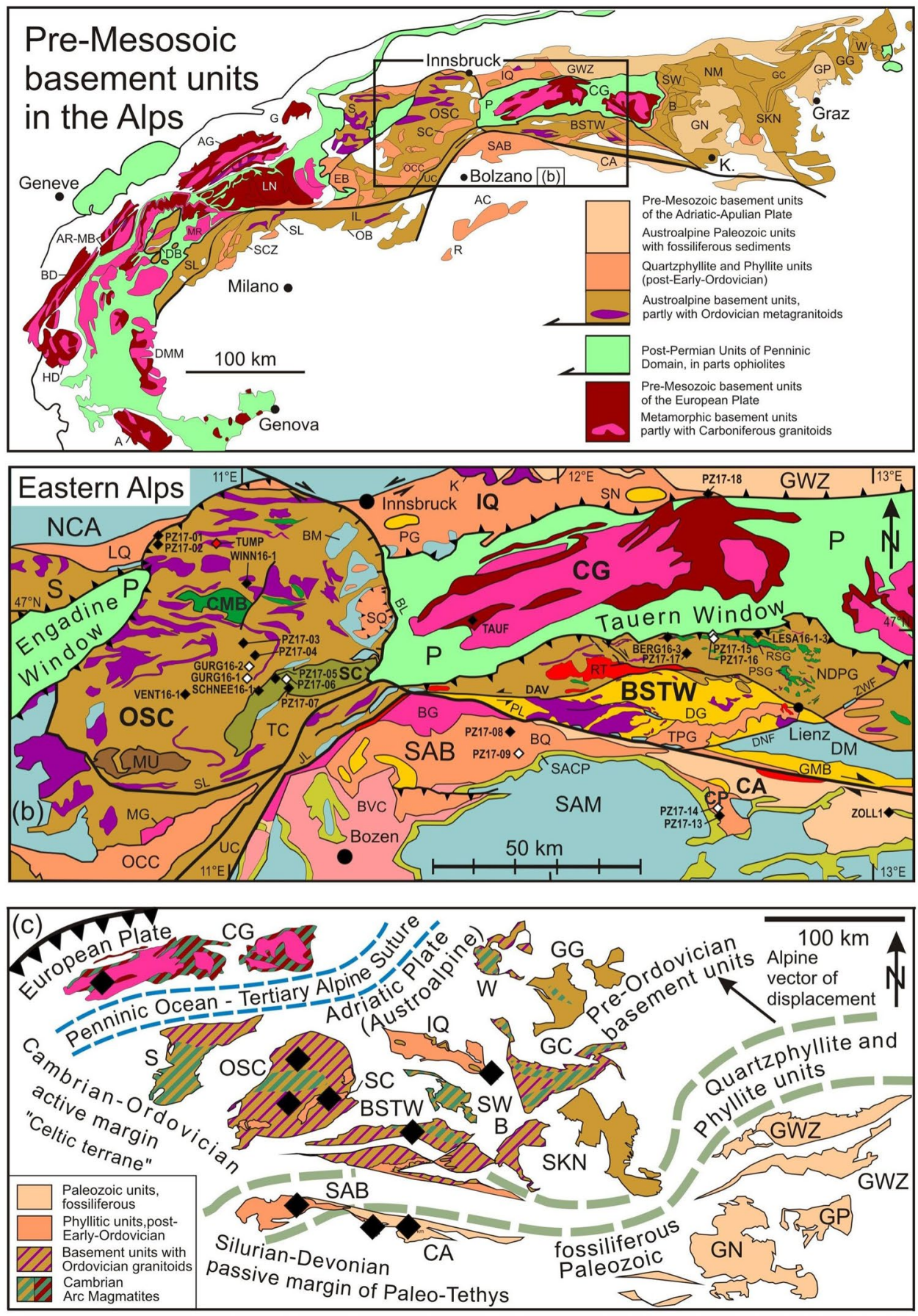

along the trench. Changes in subduction parameters such as convergence rates and slab buoyancy affect interplate coupling, thus leading to modifications in the subduction mode.

The Ediacaran to Paleozoic northern Gondwana margin is mostly represented by northern African and European basement realms, which essentially record intracontinental and marginal orogenic processes, respectively (e.g., Meinhold et al. 2011, 2013; Stephan et al. 2019a; Oriolo et al. 2021). The Ediacaran to Cambrian evolution is intimately related to the last stages of the Pan-African Orogeny, leading to the final assembly of Gondwana, and the nearly coeval Cadomian Orogeny, associated with a retreating accretionary margin, back-arc basin development and a magmatic flare-up (Linnemann et al. 2007, 2014; Murphy et al. 2013; Garfunkel 2015; von Raumer et al. 2015; Moghadam et al. 2017, 2019; Oriolo et al. 2021). Further subduction and coeval retroarc extension triggered the opening of the Rheic Ocean by the Ordovician, leading to the separation of Avalonia from the Gondwana margin and favoring crustal reworking of Cadomian domains (Murphy et al. 2006; Linnemann 
४Fig. 1 a Pre-Mesozoic basement units in the Alps and studied area, compiled according to Schulz (2008) and von Raumer et al. (2013), and references therein. Arrows in the legend indicate Cenozoic thrusting of Austroalpine basement units upon Penninic ophiolite units and pre-Mesozoic basement of the European Plate, as exposed in the Tauern Window. b Geological units and main structural features in the Eastern Alps around the western Tauern Window. Sampling locations of detrital zircon dating (black), igneous zircon dating (red) and metasediment whole-rock geochemistry (white) are marked with diamonds. Map is compiled from Schuster et al. (2015) and field observations. c Selected Alpine basement units in a pre-Mesozoic configuration, following mainly the stepwise palinpastic restoration by Ratschbacher and Frisch (1993). The main Alpine displacement vector is towards NW. Basement units belonging to a Cambrian-Ordovician active margin ("Celtic Terrane") after Frisch and Neubauer (1989). Detrital zircon sampling locations are schematically indicated by diamonds. A Argentera, $A C$ Agordo-Cereda, $A G$ Aar-Gotthard, $A R-M B$ Aiguilles Rouges Mont Blanc, $B$ Bundschuh, $B D$ Belledonne, $B G$ Brixen Granite, $B M$ Brenner Mesozoic, $B Q$ Brixen Quartzphyllite, BSTW Basement South of the Tauern Window, BVC Bozen Volcanic Complex (Permian), $C A$ Carnic Alps, $C G$ Central Gneisses of the Tauern Window, $C M B$ Central Metabasite Zone, $C P$ Comelico Phyllite, $D B$ Dent Blanche, $D G$ Defereggen Group, $D M$ Drauzug Mesozoic, $D M M$ Dora Maira Massif, $E B$ Engadine Basement, $G$ Glarus, $G C$ Gleinalm Complex, $G G$ Grobgneis, $G M B$ gailtal metamorphic basement, GN Gurktal nappes, GP Graz Paleozoic, GWZ Graywacke Zone, $H D$ Haute Dauphiné, $I Q$ Innsbruck Quartzphyllite Complex, K Kellerjoch Gneiss, $M G$ Martell Granite, $N C A$ Northern Calcareous Alps, NDPG Northern-Defereggen-Petzeck Group, NM Niedere Tauern-Micaschist Complex, $L N$ Lepontine Nappes, $L Q$ Landeck Quartzphyllite, $M R$ Monte Rosa, $M U$ Matsch Unit, $O C C$ Ortler-Campo-Complex, OSC Ötztal-Stubai-Complex, $P$ Penninic ophiolites, $P G$ Patscherkofel-Glungezer, $P S G$ Prijakt Subgroup, $R$ Recoaro, $R S G$ Rotenkogel-Subgroup, $R T$ Rieserferner Tonalite (Oligocene), $S$ Silvretta, SAB South Alpine Basement, SACP South Alpine Carboniferous-Permian sedimentary rocks, $S A M$ South Alpine Mesozoic, SC Schneeberg Complex, SCZ Strona-Ceneri Zone, SL Serie dei Laghi, $O B$ Orobic Basement, $S K N$ Saualpe-Koralpe Nappes, $S L$ Sesia-Lanzo Zone and Seconda Zona Diorite Kinzigite, $S N$ Steinkogel Nappe, $S Q$ Steinach Quartzphyllite, $S W$ SchladmingWoelz basement, TC Texel Complex, TPG Thurntaler Phyllite Group, $U C$ Ulten Complex, $W$ Wechsel Gneiss Complex. Abbreviations of main regional structures: $B L$ Brenner Line normal fault, $D A V$ Defereggen-Antholz-Vals Lineament, $D N F$ Drauzug-Nordrand Fault, $J L$ Judicarian Lineament, IL Insubric Lineament, $P L$ Pustertal Lineament, as part of the Periadriatic Lineament, $S L$ Schlinig Lineament, ZWF Zwischenbergen-Woellatratten Fault

et al. 2007; Nance et al. 2010, 2012; Stephan et al. 2019a; Oriolo et al. 2021). Long-lasting extension in the back-arc region resulted in the opening of the Paleotethys Ocean in the Silurian-Devonian (Stampfli 2000; Stampfli et al. 2002; Schulz et al. 2008; von Raumer et al. 2013), which in turn gave rise to the drift of Cadomian blocks forming the Hun superterrane (Stampfli 2000). The latter was accreted to the margin of Laurussia shortly before the Late Carboniferous Variscan collision of Gondwana mainland, which culminated with the assembly of Pangea (Stampfli et al. 2002; von Raumer et al. 2003, 2013).

There are, however, major uncertainties concerning the Ediacaran to Paleozoic evolution of Cadomian blocks. In the first place, it is unclear whether subduction was continuous or episodic. This is particularly relevant during the Ordovician opening of the Rheic Ocean, thus implying a rifted margin or, alternatively, a retreating accretionary orogen (e.g., Garfunkel 2015; Zurbriggen 2017; Stephan et al. 2019a; Oriolo et al. 2021). The nature and extension of Paleozoic oceanic basins (i.e., incipient back-arc basins vs extensive oceanic crust development) is also a critical point with deep implications for the paleogeography of Cadomian domains (e.g., Stampfli et al. 2002; Kroner and Romer 2013; von Raumer et al. 2013; Žák and Sláma 2018; Romer and Kroner 2019): did they remain attached to the northern Gondwana margin or were they drifted far away from the mainland? Therefore, the aim of this contribution is to decipher the complex pre-Variscan tectonic evolution and crustal-scale geodynamic controls of Cadomian blocks, with emphasis on the Alpine domains. For this purpose, a large database of novel whole-rock geochemical and coupled $\mathrm{U}-\mathrm{Pb}$ and Lu-Hf LA-ICP-MS zircon data of metasedimentary rocks of the Alpine basement (Austroalpine, South Alpine and Penninic Units) is integrated with geological, geochronological, isotopic and geochemical information from the literature.

\section{Geological setting}

The Eastern Alps are made up of the Austroalpine, South Alpine and Penninic Units (Schmid et al. 2020 and references therein). The former two, which are now separated by the Periadriatic Lineament, comprise basement and cover units of the Adriatic-Apulian Plate (e.g., Schmid et al. 2020 and references therein), which collided during the Alpine Orogeny with the European Plate, represented by pre-Permian basement complexes of the Penninic Unit (i.e., Subpenninic units), the External Massifs and Mesozoic oceanic deposits (Fig. 1). In the study area, the Penninic Unit is represented by the Tauern Window, which comprises European basement and cover units together with oceanic nappes. These sequences were overthrusted by Austroalpine nappes during the Alpine collision (Lammerer et al. 2008; Schmid et al. 2013).

In terms of the Alpine nappe systems, the Austroalpine basement to the west of the Tauern Window can be attributed to the Ötztal-Bundschuh nappe system, whereas the Austroalpine basement to the south of the Tauern Window belongs to the Drauzug-Gurktal nappe system (Schmid et al. 2004). The former is mainly composed of the Ötztal-Stubai Complex, which is dominated by monotonous metasiliciclastic sequences of paragneisses and micaschists (Hoinkes and Thöni 1993). In the Ötztal valley, the 8 kmthick Central Metabasite Zone is also exposed (Fig. 1b). Protoliths of the Central Metabasite Zone are gabbros and basalts with MORB chemistry (Mogessie et al. 1985) and Early Cambrian ages, emplaced in a back-arc setting 
(Miller and Thöni 1995). The Central Metabasite Zone is subdivided from north to south into five zones with variable lithologies enclosing amphibolites, eclogites and rare peridotites (Purtscheller 1978). Also, large bodies of acid orthogneissses with S- and I-type affinity are interlayered with metapsammopelitic sequences. In general, Ordovician protolith ages have been recognised for these rocks by various dating methods (Müller et al. 1996; Klötzli-Chowanetz et al. 1997; Sassi et al. 1987; Mazzoli and Sassi 1992; Schweigl 1995; Bernhard et al. 1996; Thöni 1999; Neubauer 2002). The third characteristic unit of the Austroalpine basement to the west of the Tauern Window corresponds to the Schneeberg Complex, which is exposed to the southeast of the Ötztal-Stubai Complex and contrasts with monotonous psammopelitic sequences of the latter. In the Schneeberg Complex, metapelitic sequences are interlayered with marbles, metamarls, hornblende schists and amphibolites. No protolith ages of metaigneous rocks are yet available (Hoinkes and Thöni 1993). The Ötztal-Stubai and Schneeberg Complexes are classical areas of polyphase deformation and metamorphism (Purtscheller 1978; Thöni 1999; Frisch et al. 2000). An Early Paleozoic high-temperature anatectic event was reported from the Winnebach, Verpeil and Klopaier migmatites (Klötzli-Chowanetz et al. 1997, 2001; Neubauer et al. 1999; Thöny et al. 2008). Eclogite-facies and amphibolite-facies conditions were attained during the Devonian-Carboniferous Variscan metamorphism (Miller and Thöni 1995; Mogessie and Purtscheller 1986; Tropper and Hoinkes 1996; Rode et al. 2012; Schulz et al. 2019). Likewise, an increasing grade of an Early Alpine (Cretaceous) overprint towards the south was described (Thöni 1981, 1983, 1999; Hoinkes et al. 1999; Hoinkes and Thöni 1993). This is evident from Variscan to Alpine $\mathrm{K}-\mathrm{Ar}$ and $\mathrm{Rb}-\mathrm{Sr}$ "mixed ages" of mica, changing to Cretaceous ages in the Schneeberg Complex. The successive occurrence of chloritoid and then staurolite to the southeast, accompanied by distinct growth zones in garnet porphyroblasts (Tropper and Recheis 2003) are also assigned to this Cretaceous early Alpine overprint. Cenozoic late Alpine events resulted from the indentation of the South Alpine Unit, with lateral extrusion leading to faults and shear zones which affected the Ötztal-Stubai Complex (Ratschbacher et al. 1991; Schmid et al. 2004).

On the other hand, the basement south of the Tauern Window is located between the underlying Penninic units and the Periadriatic Lineament, which represents a major Alpine boundary between the South Alpine basement and its cover sequences (Fig. 1b). Several lithological units of pre-Carboniferous rocks, dominated by metapsammopelitic sequences, can be distinguished. The northern part comprises the Northern-Defereggen-Petzeck Group (e.g., Siegesmund et al. 2018 and references theren), considered as the structurally lowermost unit. It is composed of micaschists, two-mica gneisses, biotite paragneisses, metaquartzites and some marbles. Several subgroups based on the association with metabasites can be distinguished. The structurally lowermost sequence is the Rotenkogel Subgroup, which contains hornblende gneisses with volcanic arc basalt geochemical signatures and ca. 550-533 Ma protolith crystallization ages (Schulz et al. 2004, 2008). The Torkogel, Michelbach and Croda Nera Subgroups host amphibolites with MORB to within-plate basalt geochemical fingerprint, yielding a $\mathrm{Pb}-\mathrm{Pb}$ zircon evaporation crystallization age of $430 \pm 2 \mathrm{Ma}$ (Schulz and Bombach 2003; Schulz et al. 2008). The Prijakt Subgroup is exposed in a structurally high position within the Northern-Defereggen-Petzeck Group and bears eclogitic amphibolites with N-MORB-type geochemical characteristics and a $\mathrm{Pb}-\mathrm{Pb}$ zircon evaporation protolith age of $590 \pm 4 \mathrm{Ma}$ (Schulz and Bombach 2003; Schulz et al. 2004, 2006, 2008). To the south, the Oligocene Defereggen-Antholz-Vals Line separates the Northern-Defereggen-Petzeck Group from the Defereggen Group. Both groups have pre-Early Ordovician deposition ages, as they are intruded by numerous metagranitoids with S- and I-type affinity and with Lower to Middle Ordovician crystallization ages (Schulz et al. 2004, 2008; Siegesmund et al. 2007, 2018; Heinrichs et al. 2012). The structurally overlying Thurntaler Phyllite Group has an Early Ordovician depositional age, as it comprises intercalated acid metavolcanic rocks with Ordovician protolith ages (Schulz et al. 2004, 2008; Siegesmund et al. 2007, 2018; Heinrichs et al. 2012). Further south, the Gailtal Metamorphic Basement is exposed, where four subunits were distinguished (Heinisch and Sprenger 1988; Sprenger and Heinisch 1992; Schulz et al. 1993). To the north of the Defereggen-Antholz-Vals Line, a polyphase metamorphic evolution is recorded. Carboniferous amphibolite-facies metamorphism was followed by Permian intrusion of pegmatites, succeeded by Cretaceous eclogite-facies metamorphism restricted to the Prijakt Subgroup and a final greenschist- to amphibolite-facies late Alpine metamorphic stage (Schulz et al. 1993, 2008; Krenn et al. 2012; Hauke et al. 2019).

The Innsbruck Quartzphyllite Complex to the north of the Tauern Window belongs to the Austroalpine post-EarlyOrdovician phyllitic units in the Eastern Alps (Fig. 1a, b). It has been subdivided into (1) a basal quartzphyllite-greenschist unit with an assumed Ordovician sedimentation age, (2) a carbonate-sericite phyllitic unit with metabasites and metaquartzites, and (3) a blackschist-carbonate unit that includes dolomites hosting Late Silurian to Middle Devonian conodont faunas (Höll and Maucher 1967; Haditsch and Mostler 1983; Neubauer and Sassi 1993). The Innsbruck Quartzphyllite Complex is considered the primary base of the Tarntaler Mesozoic and was overthrusted by the Patscherkofelkristallin, the Steinkogel Nappe and the Kellerjochgneis, which comprise pre-Alpine amphibolite-facies 
metamorphic Austroalpine basement units (Rockenschaub et al. 2003). Multiphase ductile deformation characterized the Innsbruck Quartzphyllite Complex, together with a metamorphic gradient from upper greenschist facies conditions to the west and lower greenschist facies conditions to the east (ca. $360^{\circ} \mathrm{C}$ and $5.4 \mathrm{kbar}$; Piber and Tropper 2005). The timing of metamorphism is commonly ascribed to the Permian and Cretaceous (Liu et al. 2001; Rockenschaub et al. 2003).

The South Alpine Unit basement to the south of the Periadriatic Lineament can be subdivided into three subunits: the Lower Pelitic-Psammitic Complex (quartzphyllites) with an assumed pre-Late Ordovician sedimentation age, the Volcano-Sedimentary Complex with the Comelico porphyroids (Söllner et al. 1997), and the Upper Pelitic-Psammitic Complex with quartzphyllites of an assumed Silurian-Devonian sedimentation age (Sassi and Spiess 1993; Arboit et al. 2019). More detailed studies in the Volcano-Sedimentary Complex revealed two main Ordovician volcanic events at ca. 470 and $450 \mathrm{Ma}$ (Arboit et al. 2019). The South Alpine basement underwent a Carboniferous multistage tectonic evolution at greenschist to lower amphibolite facies conditions (Hammerschmidt and Stöckhert 1987; Meli and Klötzli 2001; Meli 2004; Benciolini et al. 2006; Wyhlidal et al. 2010).

The Carnic Alps to the south of the Periadriatic Lineament are part of the very low- to low-grade fossiliferous Paleozoic sequences (e.g., Rantitsch 1997), which form also large parts of the Eastern Alps (Figs. 1a, b). The classic study of Schönlaub (1985) subdivided the Carnic Alps into three tectonic nappes (i.e., Fleons, Cellon-Kellerwand and Hochwipfel), though more recent studies reinterpreted lithofacies in this region as a Carboniferous olistolith flysch sequence rather than nappes (Läufer et al. 2001). The main units are the Cima Vallona metaconglomerate, the Fleons arenite and the Val Visdende Formation. The latter comprises phyllitic siliciclastic metasedimentary rocks with felsic metavolcanic intercalations (Schönlaub and Heinisch 1993; Pondrelli et al. 2015). These metavolcanic rocks, like the Comelico porphyroids, yielded conventional U-Pb zircon ages of $479 \pm 8$ and $485 \pm 8 \mathrm{Ma}$ (Meli and Klötzli 2001). In the Hochwipfel nappe, an angular unconformity separates pre-Variscan Ordovician to Early Carboniferous sequences from post-Variscan rocks, which transgresssively overlies the former (e.g., Schönlaub 1985). Pre-Variscan sequences comprise flysch sequences, including submarine fan deposits and olistoliths, which culminate with the Hochwipfel Formation (e.g., Mader et al. 2007; Spalletta et al. 2015).

In the Tauern Window, basement and cover units belonging to the European Plate are part of a huge duplex structure beneath the Penninic oceanic nappes, which are mostly composed of ophiolites and sediments from the Mesozoic Penninic Ocean. These Tauern basement units are made up of the Early Paleozoic Habach and Storz Series (Frisch et al.
1993; Höck 1993), which were intruded by numerous Variscan Carboniferous to Early Permian granitoids, such as the Zentralgneiss (Finger et al. 1993; Veselá et al. 2010).

\section{Materials and methods}

Samples of metasedimentary rocks were collected for wholerock geochemical $(n=31)$ and coupled $\mathrm{U}-\mathrm{Pb}$ and $\mathrm{Lu}-\mathrm{Hf}$ LA-ICP-MS zircon analysis $(n=18)$, comprising mainly meta-psammopelites that underwent a polyphase tectonometamorphic evolution under mostly amphibolite- to partly eclogite-facies conditions. Most samples correspond to the Austroalpine Unit, though a minor group belongs to the South Alpine and Penninic Units (Fig. 1; Supplementary Material 1). For the analysis, previous data of Austroalpine metasedimentary rocks of Heinrichs et al. (2012) and Siegesmund et al. (2018) were also considered. The sample suite encompasses pre-Permian basement rocks from several tectonic units of the Alpine orogen. For the presentation of the tectonic units, the palinspastic reconstruction of pre-Permian basement units by Ratschbacher and Frisch (1993) was considered (Fig. 1c; see also Sect. 5.1). Accordingly, Paleozoic basement rocks of the European Plate, represented by sample TAUF-1, were located to the north/northwest of the Mesozoic Penninic Ocean and the Cenozoic Alpine suture line. Towards the south/southeast, the Early Paleozoic Gondwana active margin was present, as revealed by numerous plutonic and volcanic suites with subduction-related geochemical signature (Fig. 1c). This sector is represented by samples PZ 17-01 to 07, GURG 16-1 and 2, WINN 16-1 and 2, and VENT 16-1. In a similar way, samples PZ 17-15 to 17, BERG 16-2 and 3, and LESA 16-1 to 3, of the Rotenkogel Subgroup are associated with hornblende gneisses with Cambrian protolith ages. In the Austroalpine basement, there are also numerous phyllitic units with a post-Early Ordovician to Devonian sedimentation age comprising volcanic/subvolcanic equivalents (porphyroids) of the Ordovician granitoids, represented by the Innsbruck Quartzphyllite Complex (sample PZ 17-18) and South Alpine sequences (samples PZ 17-08 to 14; Supplementary Material 1). For units with a strong Cretaceous metamorphic overprint, such as the Schneeberg Complex (samples SCHNEE 16-1 and 2), the relationship with Early Paleozoic magmatism is less clear. Further southeast, fossiliferous Late Paleozoic sedimentary rocks of the Carnic Alps (sample ZOLL-1, Hochwipfel Formation) are exposed.

For the evaluation of the mineral modes and detrital zircon 2D geometrical properties, polished thin sections from the samples were analysed by automated SEM Automated Mineralogy methods (Schulz et al. 2020). The measurement routine XMOD is a single spot point counting for mineral mode analysis, based on $\sim 10^{5}$ EDS spectra at a $10 \mu \mathrm{m}$ step 
size in a thin section. Mineral modes in wt. \% (Supplementary Material 2) were recalculated by introducing average densities listed in mineral databases. A calculated chemical assay was derived from the mineral mode, densities, and average mineral chemical compositions taken from mineral databases. The calculated assays (Supplementary Material 2) thus represent an approximation to the bulk rock composition in a given thin section plane and may differ from the bulk composition obtained from a larger volume of rock. The SPL (Sparse Phase Lineup) routine combines a backscattered electron (BSE) grey colour value trigger and single spot EDS spectral analysis. This enables the detection of accessory phases such as zircon and their intermineral relationships, and allows the quantification of their grain geometries (Supplementary Material 2).

Whole-rock major and trace element geochemical analyses were performed in metasedimentary samples comprising paragneisses, metaquartzites, micaschists and phyllites (Supplementary Material 1). Depending on grain size, $1-5 \mathrm{~kg}$ per sample were crushed. An aliquot was ground to $<200$ mesh. Major elements and Rb, Ba, Sr, Sc, Zr, Y, Nb, V, Cr, Ni were analysed by XRF (Universität Potsdam, Germany) from powder disks, whereas Cs, Ba, Sc, REE, Y, Nb, Ta, W, Co, Th, $\mathrm{Pb}$ were measured by ICP-MS and ICP-AES from solution (Georg-August-Universität Göttingen, Germany), checking results by internal and external standards.. Analytical results are presented in Supplementary Material 3.

Approximately 3-5 kg of rock material for each sample was crushed and disintegrated using disc mill to obtain a grain fraction between ca. 50-500 $\mu \mathrm{m}$ in size. The milled samples were sieved to obtain the size fraction $<315 \mu \mathrm{m}$ and this fraction was processed by using the Wilfley table to concentrate the heavy minerals. The heavy fraction of the samples was loaded to sodium polytungstate and subsequently to diiodomethane heavy liquids, followed by removal of the magnetic minerals from the heavy fraction using the Frantz isodynamic separator. Zircons were arranged in rows, cast into epoxy resin discs having a diameter of $2.54 \mathrm{~cm}$, and polished to reveal grain centers. Prior to analysis, cathodoluminescence and transmitted images were obtained so that the best sites for analysis could be chosen. Zircon analyses were performed using a Neptune multi-collector inductively coupled plasma mass spectrometer (ICP-MS) and an Analyte G2 excimer laser ablation (LA) system at the University of São Paulo (Brazil). Analytical results of $\mathrm{U}-\mathrm{Pb}$ and $\mathrm{Lu}-\mathrm{Hf}$ data are presented in Supplementary Material 4 and 5, respectively, whereas details on analytical procedures are included in Supplementary Material 6.

\section{Results}

\section{Petrography by SEM automated mineralogy}

The selection of samples from metasedimentary rocks for the study of detrital zircon requires the evaluation of the sample potential to contain a sufficient amount of zircon crystals, which have adequate characteristics for dating (e.g., grain size). A SEM automated mineralogy (SEMAM) study on petrographic thin sections may give preliminary insights (Supplementary Material 2). The samples were arranged in the table according to their modes of quartz, which range mainly between 3 and $46 \mathrm{wt}$ \%. Samples VENT 16-1 (78 wt. \%) and PZ 17-12 (0.02 wt. \%) are considered as outliers. The modes of feldspars (sum of $\mathrm{K}$-feldspar, albite and plagioclase) range between 1 and $48 \mathrm{wt} . \%$, and the general trend shows a correlation with the mode of quartz. Biotite, muscovite and chlorite are summarised as mica and range between 10 and $91 \mathrm{wt}$ \%, showing a negative correlation with quartz and feldspars. In consequence, SEM-AM data indicate that the studied sample suite comprises a wide range from metapsammitic to metapelitic compositions. The $2 \mathrm{D}$ data from zircon grains in the thin sections are subdivided in absolute area $\left(\mu \mathrm{m}^{2} \times 1000\right)$, number of grains and zircon grain size at 50 wt. $\%$ of the cumulative grain size distribution curve (reported as MD50). Zircon absolute areas range between 63 and $724 \mu \mathrm{m}^{2} \times 1000$, and show a negative correlation with the mode of quartz. However, the zircon absolute area trend displays a significant outlier (16) for sample PZ 17-16. Zircon grain counts range between 215 and 2576. The trend of increasing zircon grain counts follows the increasing mode of mica and the decreasing mode of quartz. Zircon grain size $(2-200 \mu \mathrm{m}$ length MBRminimum bounding rectangle-) cumulative distribution curves are subdivided into two groups. One group has values of MD50 between 30 and $55 \mu \mathrm{m}$, whereas the other group has lower MD50 between 10 and $25 \mu \mathrm{m}$. The general trend of decreasing zircon MD50 is correlated with the decreasing mode of quartz. For the evaluation of zircon grain properties, only grains with $>40 \mu \mathrm{m}$ length (MBR) have been considered. The grain counts of these zircon subgroup range from 2 to 265 and the trend of decreasing grain counts follow the decreasing mode of quartz and increasing mode of mica. However, sample PZ 17-16 with only 3 zircon $>40 \mu \mathrm{m}$ again constitutes an outlier.

Further 2D zircon geometric grain properties may provide information on sediment maturity and, thus, sediment transport mechanisms, since zircon mostly crystallises with long to short prismatic habitus in igneous rocks and will be successively rounded during sedimentary transport. Consequently, parameters such as aspect ratio and 
angularity of zircon grains $>40 \mu \mathrm{m}$ may be suitable for an evaluation. Since the corresponding values for aspect ratio and angularity display strong variations within each sample, not mean but median values were chosen for a comparison. The general trend of zircon $>40 \mu \mathrm{m}$ aspect ratios is increasing from 1.6 to 2.0 and follows the increasing trend of angularity values from 12 to 152 with decreasing quartz contents. The SEM-AM automated mineralogy software allows to extract data of zircon mineral association and zircon binary and ternary mineral locking (Supplementary Material 2). The trends of linear regression of zircon mineral association and mineral locking data consequently follow the modal mineralogy. Decreasing zircon mineral association and locking values follow the decreasing mode of bulk rock quartz. On the other hand, increasing values for zircon associated and locked to mica follow the increasing bulk rock mode of mica. In summary, metapsammitic rocks with elevated quartz content have an increased potential for larger detrital zircon crystals compared to mica-rich metapelitic samples.

\section{Whole-rock geochemistry}

Based on major element composition, protoliths were determined using the $\log \left(\mathrm{SiO}_{2} / \mathrm{Al}_{2} \mathrm{O}_{3}\right)$ vs $\log \left(\mathrm{Fe}_{2} \mathrm{O}_{3} / \mathrm{K}_{2} \mathrm{O}\right)$ diagram (Fig. 2a; Herron 1988). Most micaschist and paragneisses of the Ötztal-Stubai Complex correspond to shales, excepting for two samples that plot in the wacke field and sample VENT 16-1, which shows a distinct sublitharenite composition. Shales are also typical for samples of the Brixen Quartzphyllite, Agordo Phyllite and Innsbruck Quartzphyllite Complex, whereas Comelico phyllites

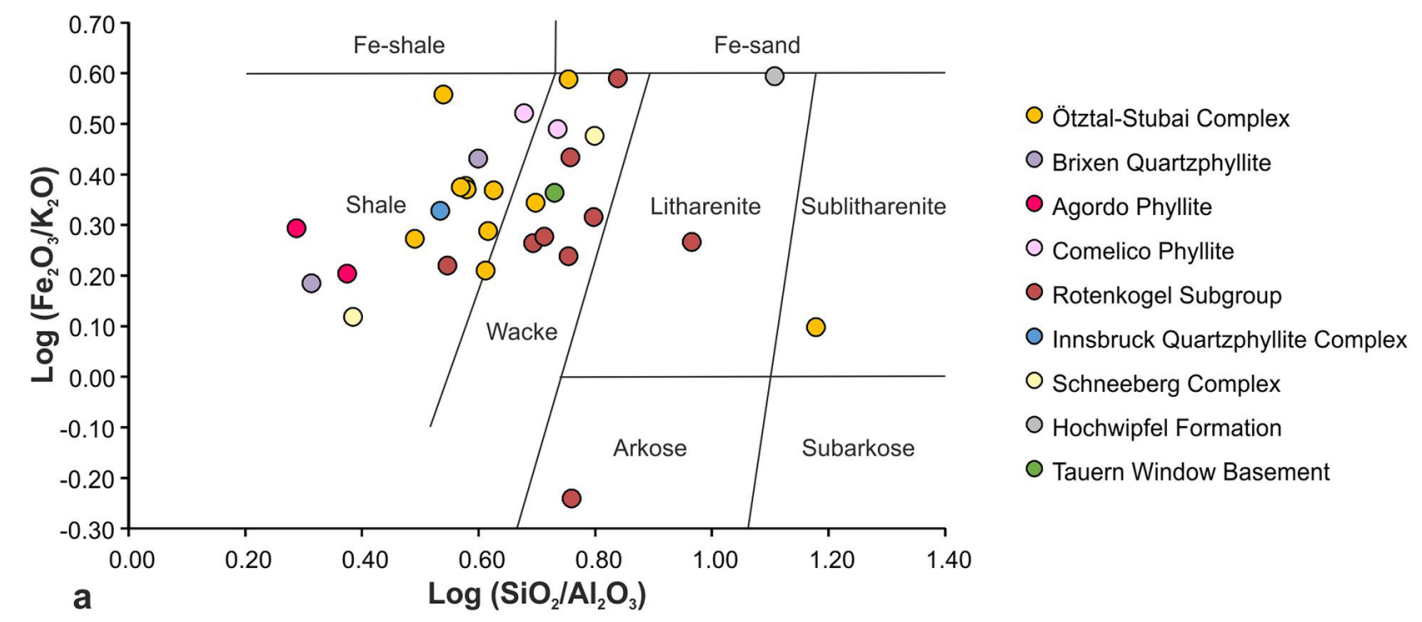

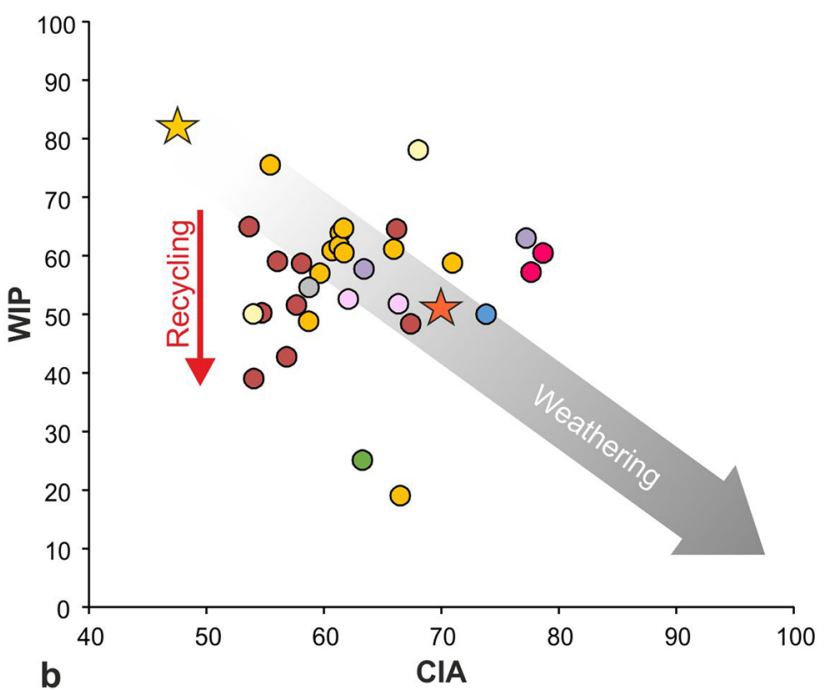

Fig. 2 Geochemical results of major elements. a Sedimentary protoliths after Herron (1988). b Chemical Index of Alteration (CIA; Nesbitt and Young 1982) vs Weathering Index (WIP; Parker 1970) plot (modified after Garzanti et al. (2013). Yellow and red starts indicate

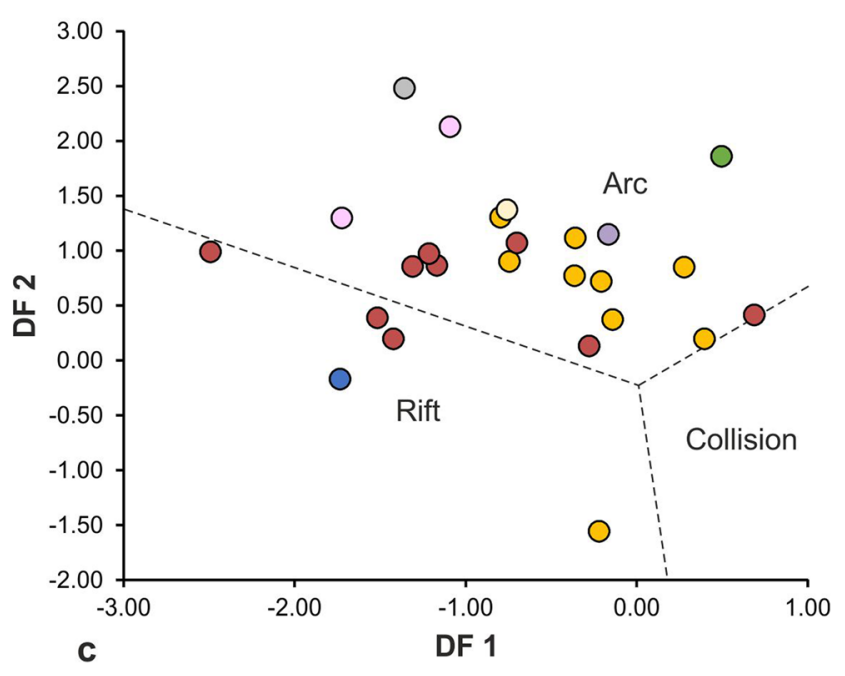

mean Upper Continental Crust and Post-Archean Australian Shale average values (Taylor and McLennan 1995; McLennan 2001). c Tectonic setting of sediment sources according to major-element discriminant function analysis (Verma and Armstrong-Altrin 2013) 
comprise shales and wackes, similarly to metasedimentary rocks of the Schneeberg Complex. On the other hand, the Rotenkogel Subgroup is dominated by wackes, expecting scarce samples that are classified as shale (PZ 17-15), litharenite (BERG 16-1) and arkose (PZ 17-16). Finally, samples of the Hochwipfel Formation and Tauern Window basement correspond to litharenite and wacke, respectively.

To evaluate the chemical weathering, the Chemical Index of Alteration (CIA; Nesbitt and Young 1982) and the Weathering Index (WIP; Parker 1970) were considered. Higher CIA and lower WIP values record higher weathering. Since WIP is proportional to the concentration of mobile elements (i.e., $\mathrm{Na}, \mathrm{Ca}, \mathrm{K}, \mathrm{Mg}$ ), it overestimates weathering due to quartz dilution, which does not affect CIA (Garzanti et al. 2013). Therefore, low WIP/CIA ratios below the expected weathering trend of first-cycle sediments are interpreted as the result of recycling. Most rocks of the studied units show moderate weathering, as indicated by CIA values between
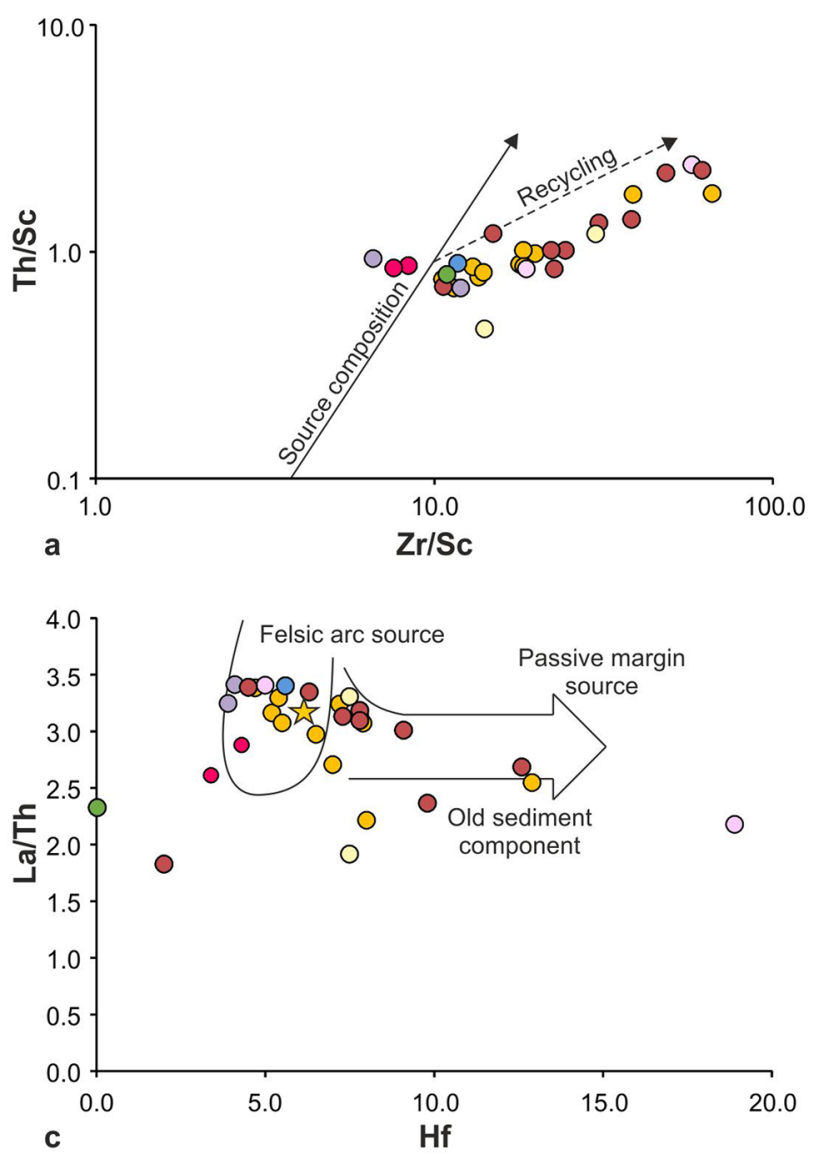

ca. 54 and 71 (Fig. 2b), whereas slightly higher values were obtained for the Brixen Quartzphyllite and Agordo phyllite samples (ca. 63-77 and 78-79, respectively). Though several samples plot along the CIA-WIP expected weathering trend, there are also significant deviations that suggest recycling. This is particularly well-recorded for the Rotenkogel Subgroup and some samples of the Ötztal-Stubai Complex, and also for individual samples of the Schneeberg Complex and Tauern Window Basement. Recycling is further supported by high $\mathrm{Zr} / \mathrm{Th}$ ratios (Fig. 3a) revealing zircon addition, with a significant deviation from the compositional variation trend (McLennan et al. 1993).

On the other hand, $\mathrm{La} / \mathrm{Sc}$ vs $\mathrm{Co} / \mathrm{Th}$ indicates a dominant felsic volcanic source, further supported by relatively high Th/U values (McLennan et al. 1993), though some samples show a granitic contribution as well (Fig. 3b; Gu et al. 2002). A felsic arc source is further supported by $\mathrm{Hf}$ vs La/ Th contents (Fig. 3c; Floyd and Leveridge 1987) and the
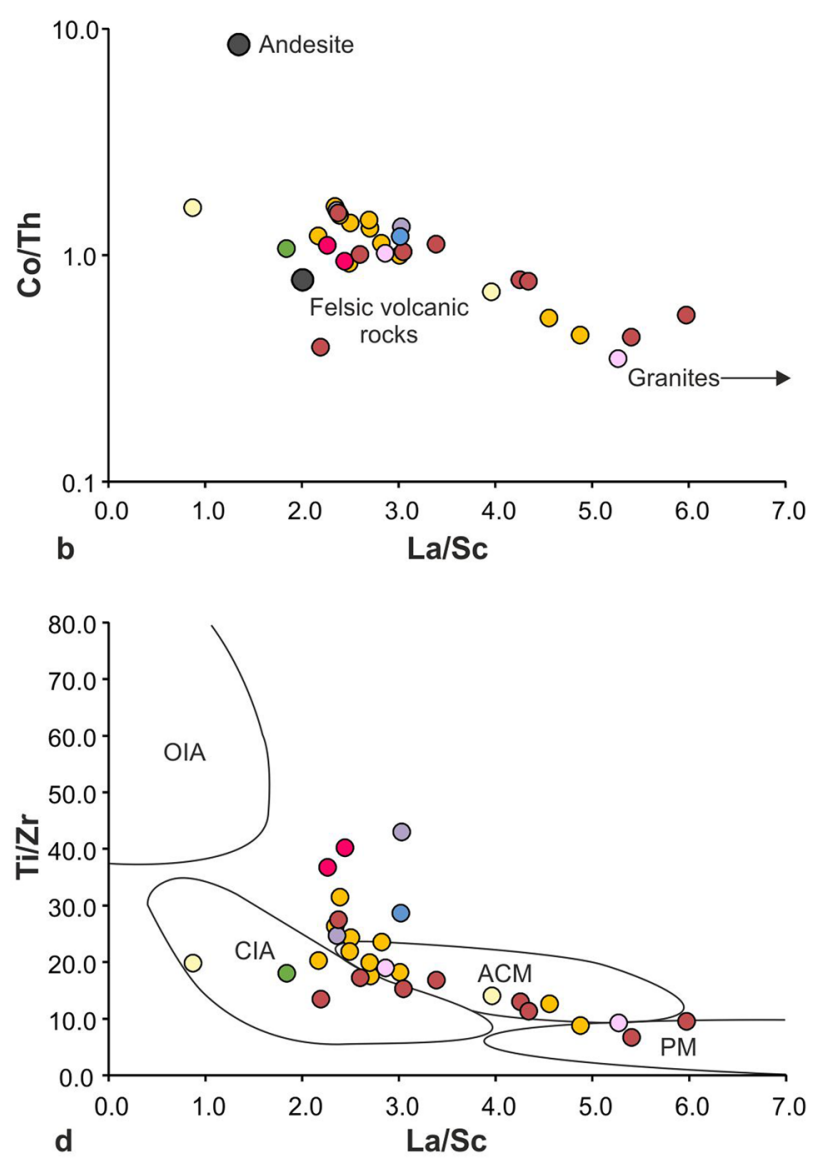

$\begin{array}{ll}\text { O Rotenkogel Subgroup } & \text { O Schneeberg Complex } \\ \text { O Innsbruck Quartzphyllite Complex } & \text { O Tauern Window Basement }\end{array}$
Fig. 3 Geochemical results of trace elements. a $\mathrm{Zr} / \mathrm{Sc}$ vs $\mathrm{Th} / \mathrm{Sc}$ (McLennan et al. 1993). b La/Sc vs $\mathrm{Co} / \mathrm{Th}$ (Gu et al. 2002). c Hf vs $\mathrm{La} / \mathrm{Th}$ (Floyd and Leveridge 1987). d La/Sc vs Ti/Zr (Bhatia and
Crook 1986). OIA oceanic island arc, CIA continental island arc, $A C M$ active continental margin, $P M$ passive margin 

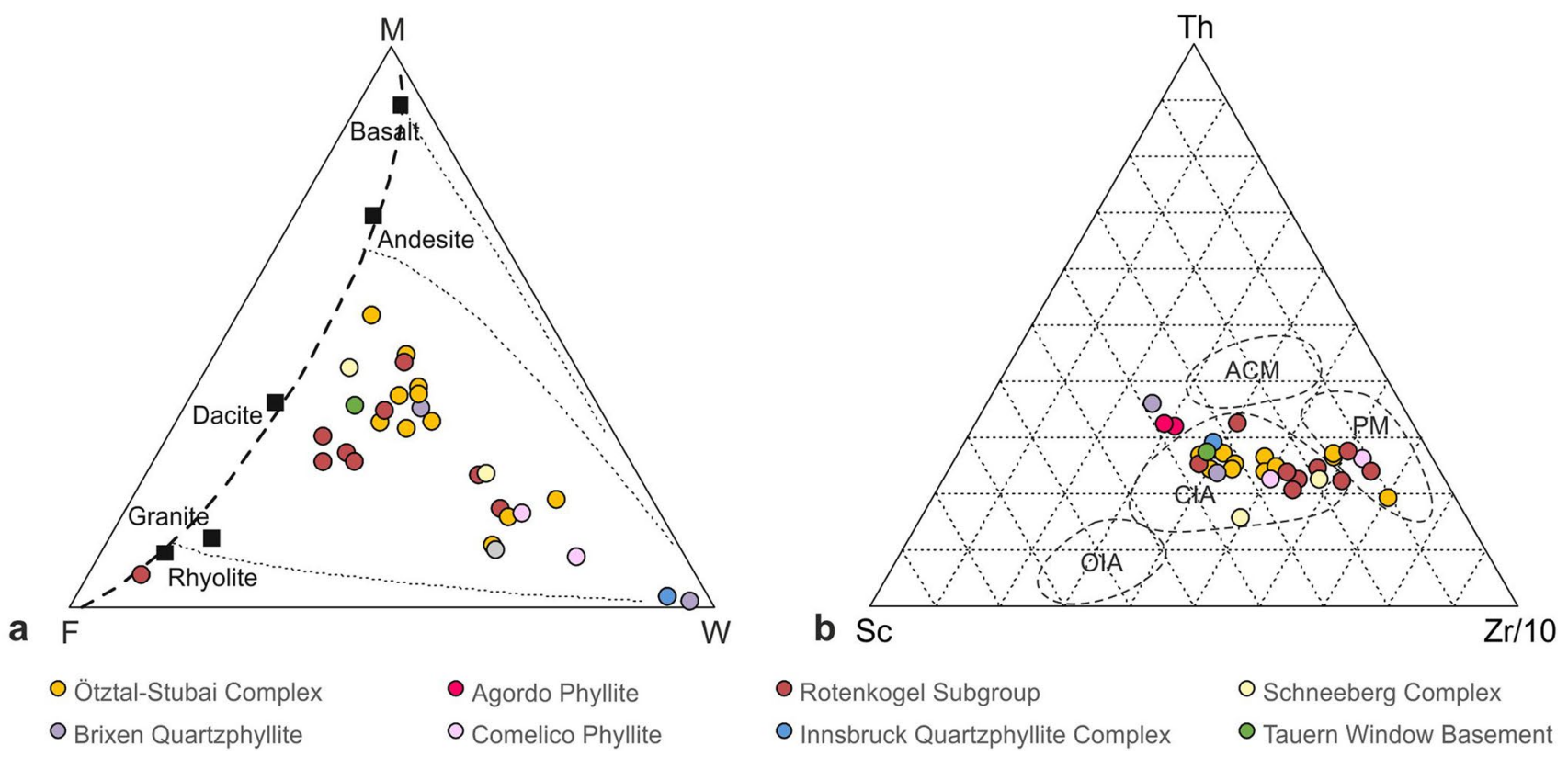

Fig. 4 a FMW ternary plot (Ohta and Arai 2007). b Th-Sc-Zr/10 tectonic discrimination diagram (Bhatia and Crook 1986). OIA oceanic island arc, $C I A$ continental island arc, $A C M$ active continental margin, $P M$ passive margin

weathering index W (Ohta and Arai 2007), which mostly indicates a dacitic affinity (Fig. 4a). However, samples of the Ötztal-Stubai Complex seem to show a slight deviation towards the andesitic trend, whereas those of the Rotenkogel Subgroup exhibit a minor rhyolitic/granitic contribution. The composition of the magmatic source is in agreement with the arc signature recorded by high-silica samples (more than $80 \%$ of the total amount) based on major element concentration (Fig. 2c; Verma and Armstron-Altrin 2013), La/Sc vs Ti/Zr (Fig. 3d; Bhatia and Crook 1986) and the Th-Sc-Zr/10 ternary plot (Fig. 4b; Bhatia and Crook 1986). Nevertheless, the latter two show some differences, since $\mathrm{La} / \mathrm{Sc}$ vs $\mathrm{Ti} / \mathrm{Zr}$ compositions reveal a dominant active continental margin setting with a minor trend towards the continental island arc field, which seems to represent the most likely setting according to the Th-Sc- $\mathrm{Zr} / 10$ ternary plot. There is also a minor group in the passive margin field, also recorded by $\mathrm{Hf}$ vs $\mathrm{La} / \mathrm{Th}$ contents, which can be explained by the aforementioned recycling, thus leading to relatively high concentrations of some trace elements due to the addition of heavy minerals (e.g., $\mathrm{Zr}$ and $\mathrm{Hf}$ in zircon).

Trace elements normalized to upper continental crust (Taylor and McLennan 1995) show a similar trend for most samples (Fig. 5), with a nearly horizontal slope and marked $\mathrm{Nb}$ and $\mathrm{Sr}$ negative anomalies. Excepting for Th and $\mathrm{K}$, which show minor enrichment and depletion, respectively, LILE contents are variable showing slighty enrichment to depletion (ca. 0.3 to $3 \times$ ). REE and HFSE are similar to or slightly enriched with respect to upper continental crust values in most cases, though minor positive anomalies of $\mathrm{Hf}$ and $\mathrm{Zr}$ are observed in some samples of the Ötztal-Stubai Complex, Rotenkogel Subgroup and Comelico Phyllite. The anomalous Hf depletion in the case of the Tauern Window Basement sample (TAUF-1) is attributed to incomplete dissolution of a Hf-bearing heavy mineral phase, possibly zircon, during LA-ICP analysis.

In a similar way, chondrite-normalized REE patterns (Boynton 1984) are also comparable for both sets of samples, showing enrichment of LREE with respect to HREE (Fig. 5) and moderate REE fractionation, as indicated by $\mathrm{La}_{\mathrm{N}} / \mathrm{Yb}_{\mathrm{N}}$ from 4.22 to 26.82 of most samples. Slightly higher $\mathrm{La}_{\mathrm{N}} / \mathrm{Yb}_{\mathrm{N}}$ values between 42.57 and 51.24 are recorded for the Agordo Phyllite and Innsbruck Quartzphyllite Complex. However, differences between XRF and LA-ICP-MS results indicate that, in some cases, minor deviations from the general trend, such as anomalously low concentrations of $\mathrm{Hf}$ and HREE (e.g., Innsbruck Quartzphyllite Complex), may result from the incomplete dissolution of accessory minerals (e.g., zircon). A slightly to moderately negative Eu anomaly is present in all samples, with $\mathrm{Eu} / \mathrm{Eu}^{*}$ values from 0.42 to 0.78 .

\section{U-Pb LA-ICP-MS}

Maximum sedimentation ages were obtained following three approaches, i.e., youngest detrital grain (YDG), youngest grain cluster at $1 \sigma$ (YCG1) and youngest grain cluster at $2 \sigma$ (YCG2) (Table 1; Dickinson and Gehrels 2009; Coutts et al. 2019). In all cases, calculations were made considering ${ }^{206} \mathrm{~Pb} /{ }^{238} \mathrm{U}$ ages, since the youngest zircons of all samples yield Ediacaran to Paleozoic ages. All calculations of the 

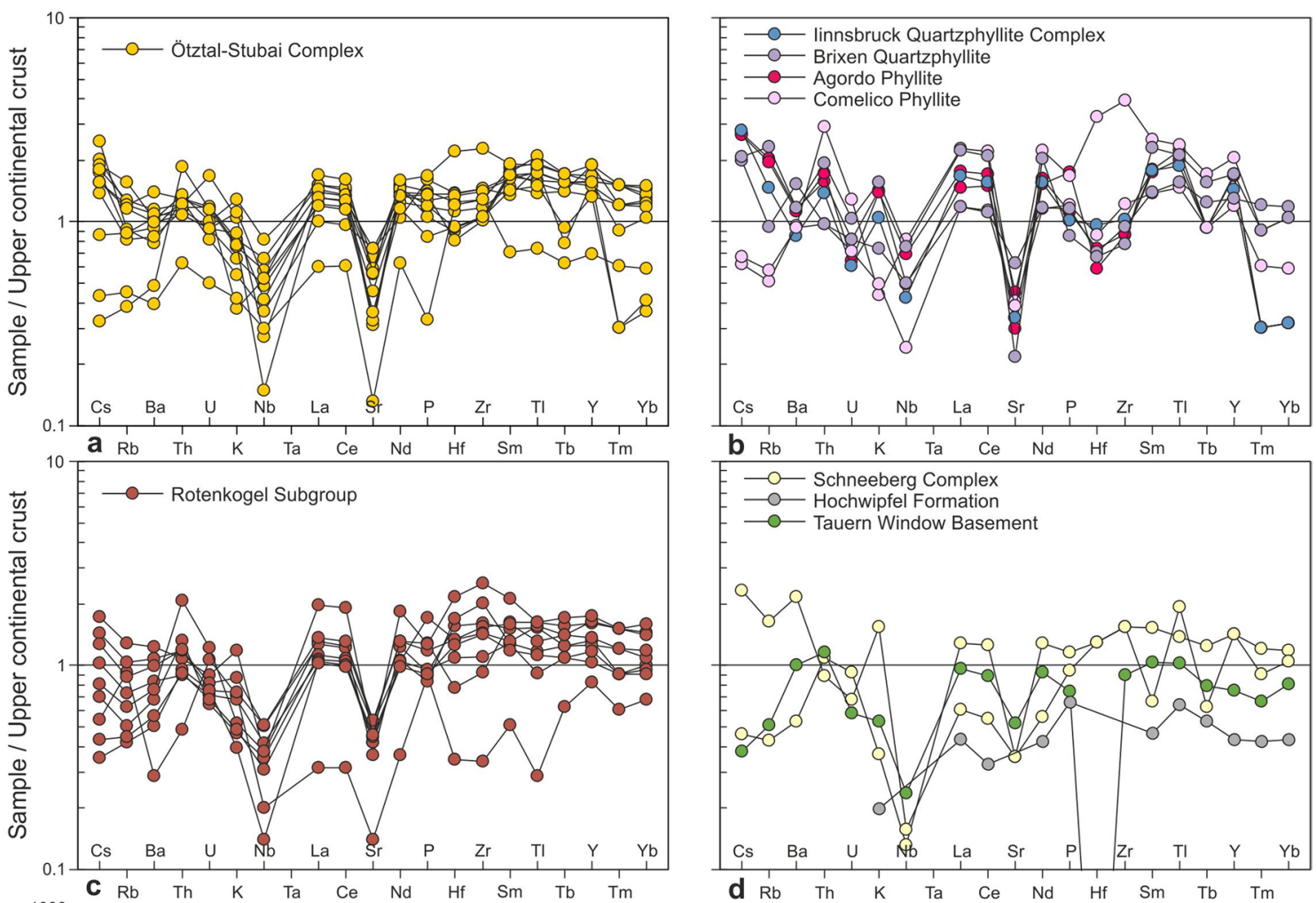

b $\mathrm{Rb}$ Th $\mathrm{K} \quad \mathrm{Ta} \quad \mathrm{Ce} \quad \mathrm{Nd} \quad \mathrm{Hf} \quad \mathrm{Sm} \quad \mathrm{Tb} \quad \mathrm{Tm}$
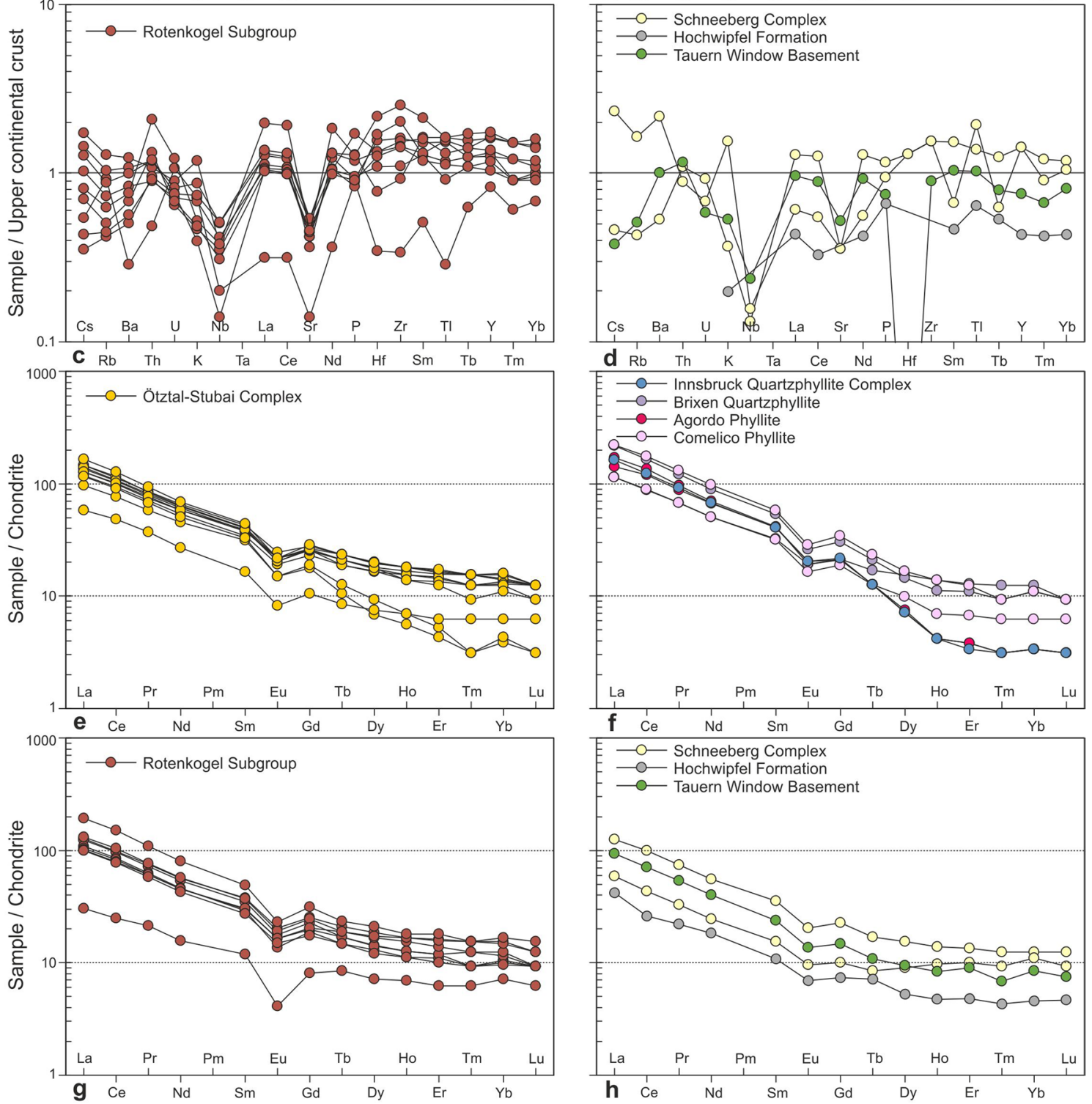

Fig. 5 Multielement (a-d) and REE (e-h) variation diagrams normalized to upper continental crust (Taylor and McLennan 1995) and chrondrite (Boynton 1984), respectively 
Table 1 Maximum sedimentation and metamorphism ages

\begin{tabular}{|c|c|c|c|c|c|c|}
\hline Sample & Lithology & Unit & YSG & $\mathrm{YC} 1 \sigma$ & $\mathrm{YC} 2 \sigma$ & $\begin{array}{l}\text { Metamor- } \\
\text { phism (single } \\
\text { grain) }\end{array}$ \\
\hline PZ 17-02 & Micaschist & Ötztal-Stubai Complex & $494 \pm 7,544 \pm 4$ & $564 \pm 4$ & $564 \pm 3$ & $407 \pm 3$ \\
\hline PZ 17-03 & Micaschist & & $532 \pm 3$ & $553 \pm 3$ & $555 \pm 2$ & $476 \pm 3$ \\
\hline PZ 17-04 & Micaschist & & $580 \pm 5$ & $580 \pm 3$ & $581 \pm 2$ & $\mathrm{x}$ \\
\hline PZ 17-05 & Micaschist & & $490 \pm 3,501 \pm 5$ & $558 \pm 2$ & $559 \pm 2$ & $469 \pm 4$ \\
\hline PZ 17-07 & Micaschist & & $557 \pm 8$ & $575 \pm 2$ & $576 \pm 5$ & $482 \pm 3$ \\
\hline WINN 16-1 & Paragneiss & & $536 \pm 3$ & $537 \pm 2$ & $538 \pm 2$ & $\mathrm{x}$ \\
\hline VENT 16-1 & Paragneiss & & $568 \pm 3$ & $583 \pm 3$ & $584 \pm 3$ & $\mathrm{x}$ \\
\hline PZ 17-08 & Micaschist & Brixen Quartzphyllite & $543 \pm 5$ & $566 \pm 4$ & $567 \pm 3$ & $\mathrm{x}$ \\
\hline PZ 17-13 & Phyllite & Comelico Phyllite & $547 \pm 6$ & $581 \pm 3$ & $582 \pm 2$ & $439 \pm 4$ \\
\hline PZ 17-17 & Micaschist & Rotenkogel Subgroup & $556 \pm 3$ & $567 \pm 3$ & $568 \pm 2$ & $535 \pm 4$ \\
\hline BERG 16-3 & Paragneiss & & $553 \pm 7$ & $554 \pm 5$ & $555 \pm 3$ & $542 \pm 4$ \\
\hline LESA $16-1$ & Paragneiss & & $554 \pm 5$ & $557 \pm 2$ & $559 \pm 2$ & $534 \pm 4$ \\
\hline LESA $16-2$ & Paragneiss & & $556 \pm 4$ & $558 \pm 3$ & $561 \pm 3$ & $544 \pm 3$ \\
\hline LESA $16-3$ & Paragneiss & & $556 \pm 3$ & $557 \pm 3$ & $560 \pm 4$ & $536 \pm 3$ \\
\hline PZ 17-18 & Micaschist & Innsbrucker Quartzphyllite Complex & $480 \pm 3$ & $568 \pm 3$ & $568 \pm 3$ & $423 \pm 3$ \\
\hline SCHNEE 16-1 & Metawacke & Schneeberg Complex & $440 \pm 3,572 \pm 6$ & $578 \pm 4$ & $580 \pm 2$ & $332 \pm 3$ \\
\hline ZOLL-1 & Sandstone & Hochwipfel Formation & $341 \pm 5$ & $342 \pm 4$ & $344 \pm 3$ & $\mathrm{x}$ \\
\hline TAUF-1 & Paragneiss & Tauern Window Basement & $394 \pm 3,409 \pm 4$ & $448 \pm 3$ & $450 \pm 7$ & $387 \pm 3$ \\
\hline
\end{tabular}

Ages in Ma, all errors at $\pm 1 \sigma$. YSG youngest single grain, $Y G C 1$ youngest grain cluster at $1 \sigma(n=2), Y G C 2$ youngest grain cluster at $2 \sigma(n=3)$. In those cases where the detrital/metamorphic origin of single grain ages was ambiguous, two single grain ages are indicated (i.e., the two youngest ages for maximum sedimentation and the two oldest for metamorphism)

youngest cluster weighted mean age were based on $n=2$ and $n=3$ for ages overlapping at $1 \sigma$ and $2 \sigma$, respectively. On the other hand, minimum sedimentation ages were inferred considering the oldest grain age interpreted as a metamorphic overgrowth and, when possible, ages of metamorphism were also calculated for two or more grains. Metamorphic zircons were identified based on CL textural evidence and/ or chemical compositions (e.g., Th/U; Fig. 6).

In the first place, most samples of the Ötztal-Stubai Complex show clear age constraints indicating Late Ediacaran maximum sedimentation ages based on YGC1 and YGC2, excepting for sample WINN 16-1, which shows a welldefined Early Cambrian age (Table 1). However, Cambrian ages are evident for some samples according to YGC1 and YSG estimations. Though the YGC2 is the most statistically robust approach, these Early Paleozoic ages seem to be valid as well. Therefore, maximum sedimentation ages vary between the Late Ediacaran and Cambrian, suggesting either minor differences in the sediment source or the existence of units yielding slightly different ages. On the other hand, ages of metamorphism provide a minimum Ordovician to Devonian age for four samples (PZ 17-02, PZ 17-03, PZ 17-05, PZ 17-07). The sedimentation age of the protolith of metasedimentary rocks of the Ötztal-Stubai Complex seem thus to be restricted to the Late Ediacaran to middle Cambrian, with a dominance of Early Paleozoic ages. In terms of provenance, nearly all samples are characterized by a main contribution of zircons yielding ages between ca. 570 and $670 \mathrm{Ma}$, with a peak at ca. 630-600 Ma (Table 2, Supplementary Material 4). The only exception is sample VENT 16-1, which is dominated by ages of ca. 1030-980 Ma, though Early Ediacaran ages are also well-documented. Despite being subordinate, the contribution of Late Stenian to Cryogenian zircons is also clear, defining two main groups of ca. 830-710 and 1050-900 Ma, whereas a minor Neoarchean to Paleoproterozoic population is ubiquitously present in all samples. Finally, samples yielding well-defined Early Paleozoic maximum sedimentation ages exhibit ages of ca. 540-530. Detrital zircon data are also in agreement with the crystallization age of $479 \pm 3$ Ma obtained for an orthogneiss (Sample TUMP) intercalated with metasedimentary rocks (Fig. 6b), which also provides a minimum age for sedimentation and contains Paleoproterozoic to Cambrian inherited zircon xenocrysts (Supplementary Material 4).

For the Rotenkogel Subgroup, the YGC2 indicates nearly comparable Late Ediacaran maximum sedimentation ages for all samples (Table 1). On the other hand, provenance results are comparable to those of the Ötztal-Stubai Complex, with a main peak at ca. 630-600 Ma of zircons scattering mostly between ca. 660 and $580 \mathrm{Ma}$ (Table 2, Supplementary Material 4). In a similar way, subordinate groups at ca. 1000-930, 890-840 and 790-700 Ma are also present, 
Fig. 6 a Age vs Th/U for Late Ediacaran to Cenozoic zircons. Inset show representative cathodoluminiscence images of metamorphic zircons. b Concordia age for crystallization age of orthogneiss sample TUMP. c Concordia age for metamorphism of sample TAUF-1

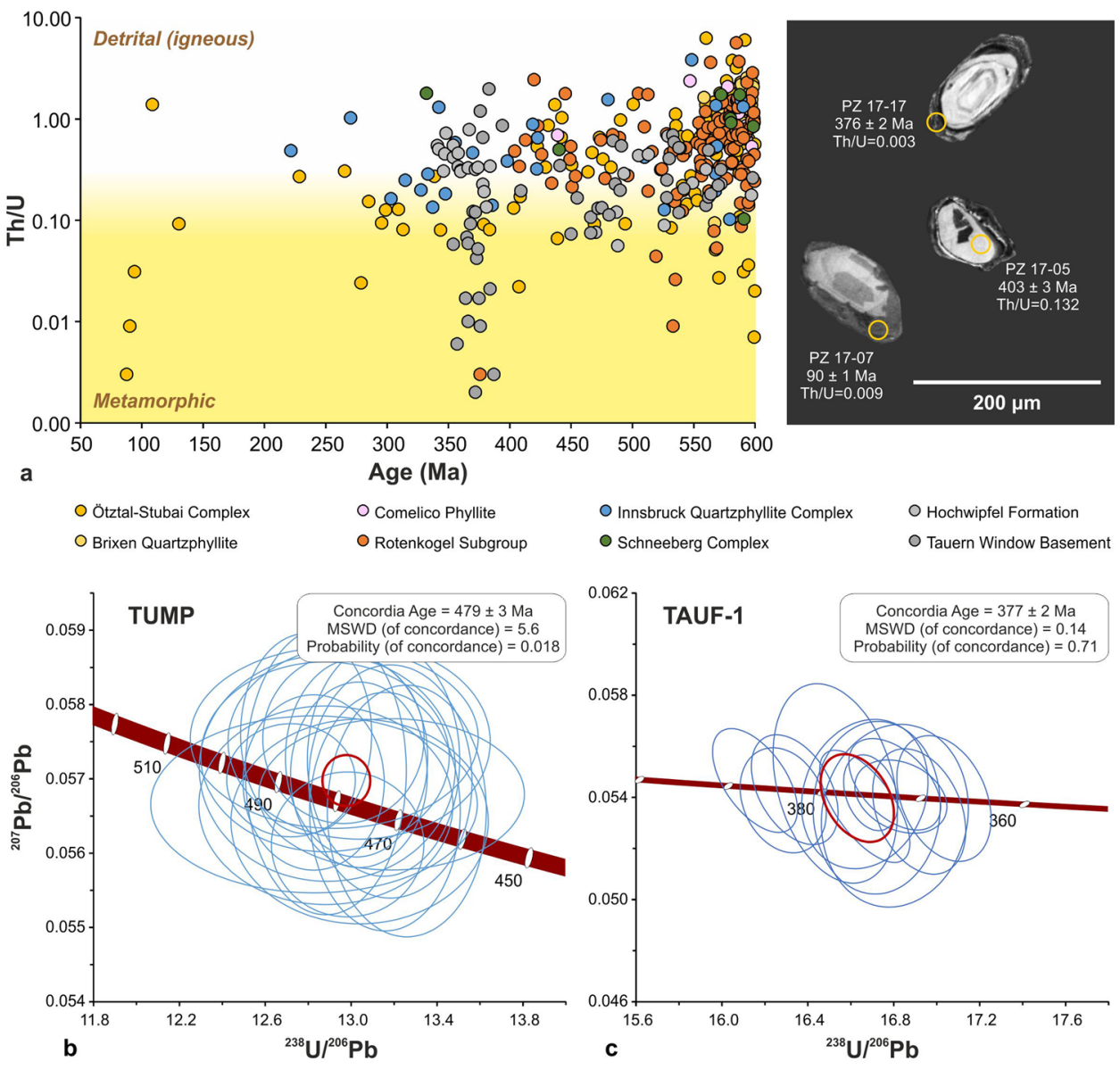

together with a minor contribution of Paleoproterozoic and Neoarchean grains.

Results of the Schneeberg Complex show a clear Late Ediacaran maximum sedimentation age (Table 1). However, the YSG suggests a possible Early Silurian age $(440 \pm 3 \mathrm{Ma}$; Supplementary Material 4), though the detrital vs metamorphic origin of this grain is unclear. In addition, an Early Carboniferous metamorphic overgrowth sets the minimum age for the sequence. The main detrital contribution is represented by zircons yielding ages of ca. 670-580 Ma, with a peak at ca. $650 \mathrm{Ma}$ (Table 2, Supplementary Material 4). In addition, minor groups at ca. 1070-960 and 810-760 Ma are present as well, together with scarce Neoarchean and Late Paleoproterozoic grains.

The Innsbruck Quartzphyllite Complex (sample PZ 17-18) shows a well-defined Late Ediacaran maximum sedimentation age based on YGC2 (568 $\pm 3 \mathrm{Ma})$ and $\mathrm{YGC} 1$ $(568 \pm 3 \mathrm{Ma})$, though the YSG indicates an Early Ordovician age $(480 \pm 3 \mathrm{Ma}$; Table 1). Late Silurian to Devonian overgrowths set a minimum age for the unit, allowing to define a Middle Ordovician to Early Silurian sedimentation age. Whether these ages truly represent a metamorphic overprint is however unclear, since relatively high discordance relative to the ${ }^{207} \mathrm{~Pb} /{ }^{206} \mathrm{~Pb}$ ages may alternatively suggest a disturbed system. Likewise, the low metamorphic grade of the phyllites rules out a metamorphic overgrowth of the zircons and, therefore, these ages might have resulted from $\mathrm{Pb}$ loss, related to Permian thermal overprint, Alpine deformation and fluid migration, and/or recent loss processes. Provenance is characterized by a main peak at ca. $580-550 \mathrm{Ma}$ (Table 2, Supplementary Material 4). Subordinate groups yielding ages of ca. 980-940 and 730-680 Ma, together with scattered Neoarchean to Paleoproterozoic grains, are also documented.

Sample PZ 17-08 of the Brixen Quartzphyllite shows well-constrained comparable YGC2 and YGC1 Late Ediacaran ages (567 \pm 3 and $566 \pm 4 \mathrm{Ma}$, respectively; Table 2). The YSG age of $543 \pm 5 \mathrm{Ma}$, however, may suggest a possible Early Cambrian maximum sedimentation age. The provenance is characterized by a main peak at ca. $590 \mathrm{Ma}$, corresponding to a large group of grains yielding ages between ca. 610 and $550 \mathrm{Ma}$, followed by secondary peaks at ca. 700, 640 and $850 \mathrm{Ma}$, and minor Neoarchean to Paleoproterozoic contribution (Table 2, Supplementary Material 4).

In the case of the Comelico Phyllite, all calculations of the maximum deposition age indicate a Late Ediacaran age (Table 1), possibly close to the Ediacaran-Cambrian transition, according to the YSG (547 $\pm 6 \mathrm{Ma})$. The main detrital 


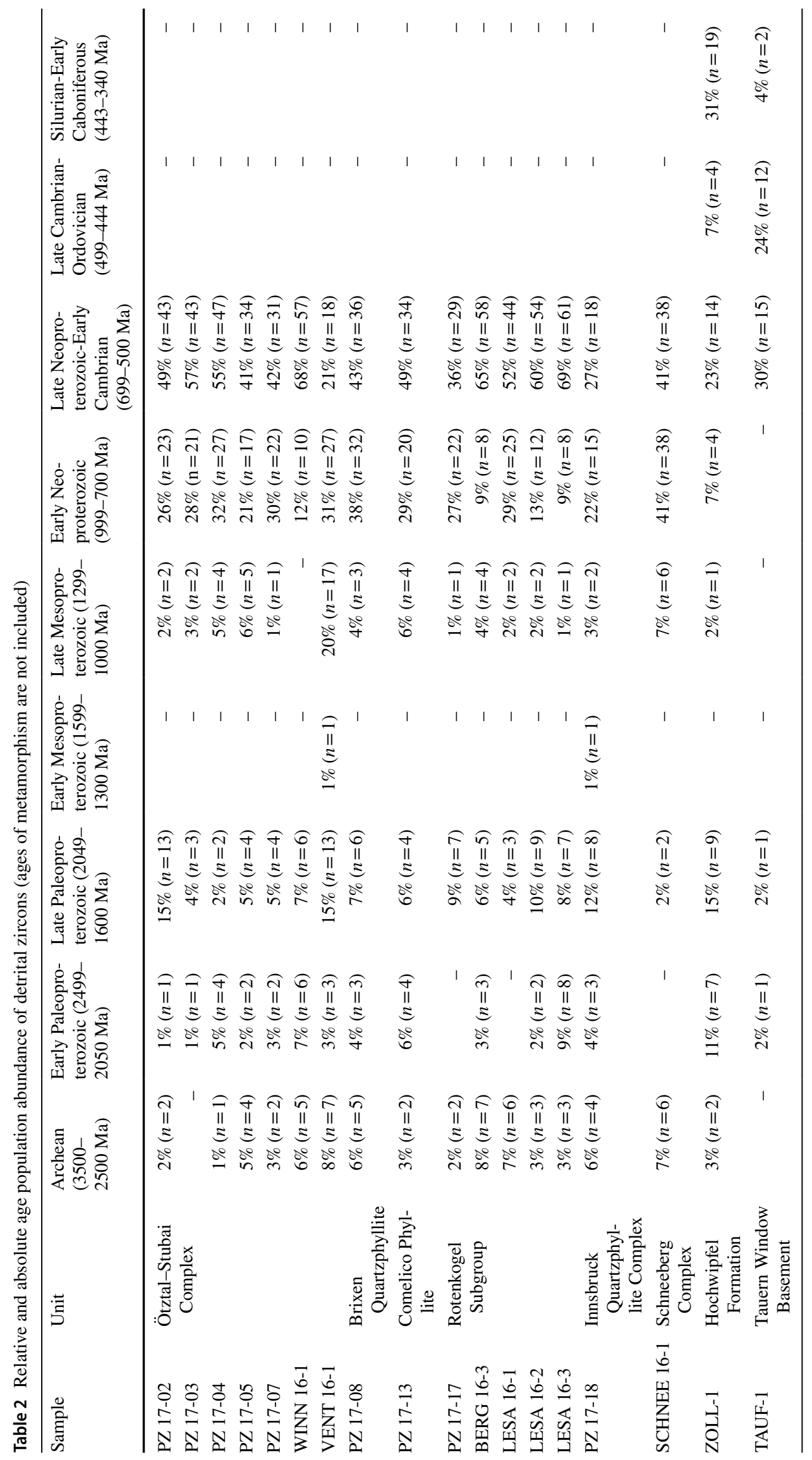


contribution corresponds to ages of ca. $650-570 \mathrm{Ma}$, with a peak at ca. $600 \mathrm{Ma}$ (Table 2, Supplementary Material 4). Subordinate zircon populations yield ages of ca. 1040-1000, 970-920 and 770-740 Ma. Finally, few Neoarchean and Paleoproterozoic grains are also documented.

The sample of the Hochwipfel Formation yielded nearly comparable YGC2, YGC1 and YSG results $(344 \pm 3,342 \pm 4$ and $341 \pm 5 \mathrm{Ma}$, respectively), providing a robust Early Carboniferous maximum sedimentation age. In contrast to all previous units, sample ZOLL-1 is characterized by a main peak at ca. $350 \mathrm{Ma}$, representing a large group of ages between 370 and $330 \mathrm{Ma}$ (Table 2, Supplementary Material 4). Minor groups at ca. 540-470, 690-640 and 2150-1950 Ma are also documented, together with scattered Neoarchean, Early Paleozoproterozoic and Mesoproterozoic grains.

Finally, sample TAUF-1 of the Tauern Window exhibits comparable Late Ordovician ages according to YGC2 and YGC1, though Early Devonian individual zircons are also present. On the other hand, several Middle to Late Devonian metamorphic overgrowths provide a robust indication for the minimum age of the sequence, further supported by a concordia age of $377 \pm 2$ Ma for the metamorphic overprint (Fig. 6c). Provenance of this sample is also distinct, with a main peak at ca. 530-510 Ma, followed by a secondary group of ca. 580-550 Ma (Table 2, Supplementary Material
4). Pre-Ediacaran ages are restricted to only two Paleoproterozoic grains.

In addition to the Ordovician to Early Carboniferous metamorphic ages that constrain the minimum age of sedimentation (e.g., Table 1), younger metamorphic zircon overgrowths are recorded in samples of the Öztal-Stubai Complex and the Innsbruck Quartzphyllite Complex (Supplementary Material 4). They yield Late Carboniferous (ca. 323-299 Ma), Permian (ca. 296-268 Ma) and Cretaceous (ca. 130-88 Ma) ages, besides one minor Late Triassic population (ca. 229-222 Ma).

\section{Lu-Hf isotopes}

In the first place, results show that coeval detrital zircons of different stratigraphic units show similar Lu-Hf signature, indicating that no major differences are recorded among them. Neoarchean zircons yield variable isotopic fingerprint, with variable values between ca. -8 and +7 (Fig. 7a), whereas Paleoproterozoic grains are mostly characterized by subchondritic compositions with $\varepsilon_{\mathrm{Hf}}$ up to ca. - 15. Interestingly, these Paleoproterozoic and Neoarchean compositions are aligned along an apparent crustal array with ${ }^{176} \mathrm{Lu} /{ }^{177} \mathrm{Hf}=0.015$, typical for a crustal reservoir (e.g., Griffin et al. 2002).
Fig. 7 a $\mathrm{U}-\mathrm{Pb}$ vs. $\varepsilon_{\mathrm{Hf}}$ data of studied units. $\mathbf{b}$ Compilation of detrital zircon $\mathrm{U}-\mathrm{Pb}$ vs. $\varepsilon_{\mathrm{Hf}}$ data of the Alpine basement (this work; Siegesmund et al. 2018) and Cretaceous to Cenozoic sequences (Chu et al. 2016). Arrows indicate pulses of mantle-derived juvenile magmatism addition during the Cadomian, Cenerian and Variscan events. Data were recalculated considering a constant decay $\lambda^{176} \mathrm{Lu}=1.867 \times 10^{-11}$ year $^{-1}$ (Söderlund et al. 2004) and CHUR values of ${ }^{176} \mathrm{Hf} /{ }^{177} \mathrm{Hf}=0.282785$ and ${ }^{176} \mathrm{Lu} /{ }^{177} \mathrm{Hf}=0.0336$ (Bouvier et al. 2008)
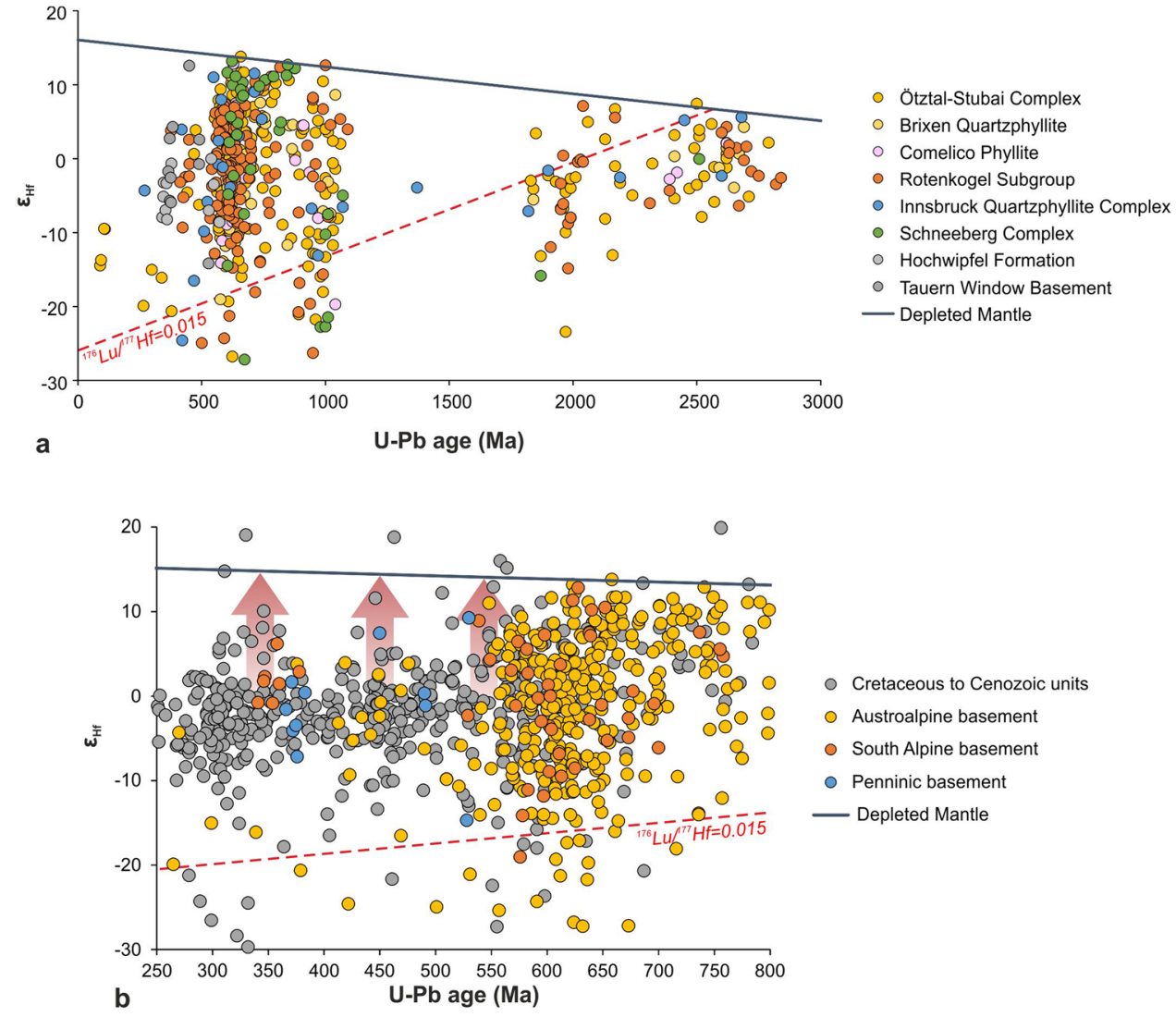
Stenian to Early Tonian grains shows a large variability of Lu-Hf compositions, as recorded by $\varepsilon_{\mathrm{Hf}}$ values between ca. -26 and +12 . In particular, those grains yielding the most subchondritic compositions seem to be aligned with Paleoproterozoic and Neoarchean zircons along with the aforementioned crustal array. In contrast, Late Tonian to Early Cryogenian grains show slightly subchrondritic to suprachondritic $\varepsilon_{\mathrm{Hf}}$ (ca. -7 to +12 ), showing the dominance of the latter. In a similar way to Stenian-Early Tonian zircons, the isotopic fingerprint of Late Cryogenian to Ediacaran crystals is variable, with $\varepsilon_{\mathrm{Hf}}$ values between ca. -26 and +12 . Though scarce, Late Ediacaran to Cambrian zircons exhibit a more narrow variability, with subchrondritic to suprachondritic $\varepsilon_{\mathrm{Hf}}$ between ca. -14 and +8 . Finally, subchondritic to slightly suprachondritic compositions varying mostly from ca. +4 to -9 were obtained for Ordovician to Carboniferous grains, including metamorphic overgrowths of sample TAUF- 1 .

\section{Discussion}

\section{Age and provenance}

All studied Austroalpine units, namely the Ötztal-Stubai Complex, Rotenkogel Subgroup, Schneeberg Complex and Innsbruck Quartzphyllite Complex, seem to be pre-Carboniferous (see below), according to maximum sedimentation and metamorphic ages (Table 1), being thus coeval with other metasedimentary units of the Austroalpine basement (Heinrichs et al. 2012; Siegesmund et al. 2018). Though Late Ediacaran maximum sedimentation ages are constrained by most YGC2 values for the Ötztal-Stubai Complex, several samples exhibit younger Cambrian ages indicated by YGC1 and YSG (Table 1; PZ 17-03, PZ 17-05, WINN 16-1), together with Ordovician to Devonian metamorphism. Differences obtained between samples may indicate either minor variations in terms of provenance or slightly different sedimentation ages (Table 2, Supplementary Material 4). The existence of pre-Ordovician sedimentary sequences in the Ötztal-Stubai Complex are supported by $\mathrm{Pb}-\mathrm{Pb}$ evaporation and U-Pb TIMS zircon data of the Winnebach migmatite, which records anatexis of paragneisses at ca. 490-485 Ma (Klötzli-Chowanetz et al. 1997), and EPMA Th-U-Pb monazite ages in different migmatic units revealing partial melting at ca. $441 \mathrm{Ma}$ (Thöny et al. 2008). Further evidence is provided by the U-Pb zircon age of ca. $479 \mathrm{Ma}$ of the intercalated orthogneiss (sample TUMP, Fig. 6b) and Ordovician to Devonian ages interpreted as the result of metamorphism, which are recorded in the studied samples (Table 1).

The presence of Late Ediacaran sequences in the Rotenkogel Subgroup, as indicated by detrital zircon data of all samples (Table 1), is further supported by intercalations of hornblende-bearing orthogneisses yielding $\mathrm{Pb}-\mathrm{Pb}$ evaporation ages of ca. 551-543 Ma (Schulz and Bombach 2003). Similar results were reported for other subunits of the Northern-Defereggen-Petzeck Group, which record Late Ediacaran to Middle Cambrian maximum sedimentation ages and Late Ediacaran to Silurian magmatism (Schulz and Bombach 2003; Heinrichs et al. 2012; Siegesmund et al. 2018).

Results of sample SCHNEE 16-1 of the Schneeberg Complex show a well-constrained late Ediacaran maximum sedimentation age, though one ambiguous zircon suggests an Early Silurian maximum age. Considering the evidence of Mississipian metamorphism, the sedimentation age of the Schneeberg Complex sedimentary protolith can thus be roughly assigned to the Early to Middle Paleozoic. In a similar way, sample PZ 17-18 of the Innsbruck Quartzphyllite Complex yields a likely Ordovician sedimentation age, according to the YSG, ages of overprint and acritarch content (Reitz and Höll 1990).

In the case of South Alpine units, samples of the Brixen Quartzphyllite (PZ 17-08) and Comelico Phyllite (PZ 17-13) show Late Ediacaran maximum sedimentation ages (Table 1), which is younger than Late Cryogenian detrital zircon ages reported by Wyhlidal et al. (2010) and comparable with maximum sedimentation ages of the Val Visdende Formation (Siegesmund et al. 2018). These results are further supported by the minimum ages set by Early Ordovician felsic volcanic to subvolcanic bodies (Meli and Klötzli 2001) and zircon metamorphic overgrowths of the Comelico Phyllite, together with palynological evidence of the Agordo Phyllite showing an age range from Cambrian to SilurianDevonian? (Sassi et al. 1984; Dieni et al. 2005).

On the other hand, sample ZOLL-1 of the Hochwipfel Formation shows a very robust maximum sedimentation age of ca. 344-341 Ma constrained by all calculated parameters (Table 1), which is slightly younger than Devonian ages constrained by Ar/Ar detrital mica data (Mader et al. 2007). Considering also Ar/Ar detrital white mica ages of ca. 331-309 Ma of the overlying Auernig Group, a dominantly Visean sedimentation age can be inferred for the Hochwipfel Formation, further supported by paleontological evidence (Krainer and Vachard 2015; Kabon and Schönlaub 2019).

Finally, sample TAUF-1 of the Penninic Unit shows an Early to Middle Devonian sedimentation age for paragneisses of the Tauern Window Basement, constrained by YSG of ca. 409-394 Ma and Late Devonian metamorphism. This unit seems thus to be slightly older than Late Devonian to Early Carboniferous maximum sedimentation ages reported by Kebede et al. (2005) for paragneisses and schists exposed further east.

In sum, studied units seem to record distinct stages of a Late Ediacaran to Carboniferous sedimentation in the construction of the proto-Alps. However, no major differences 

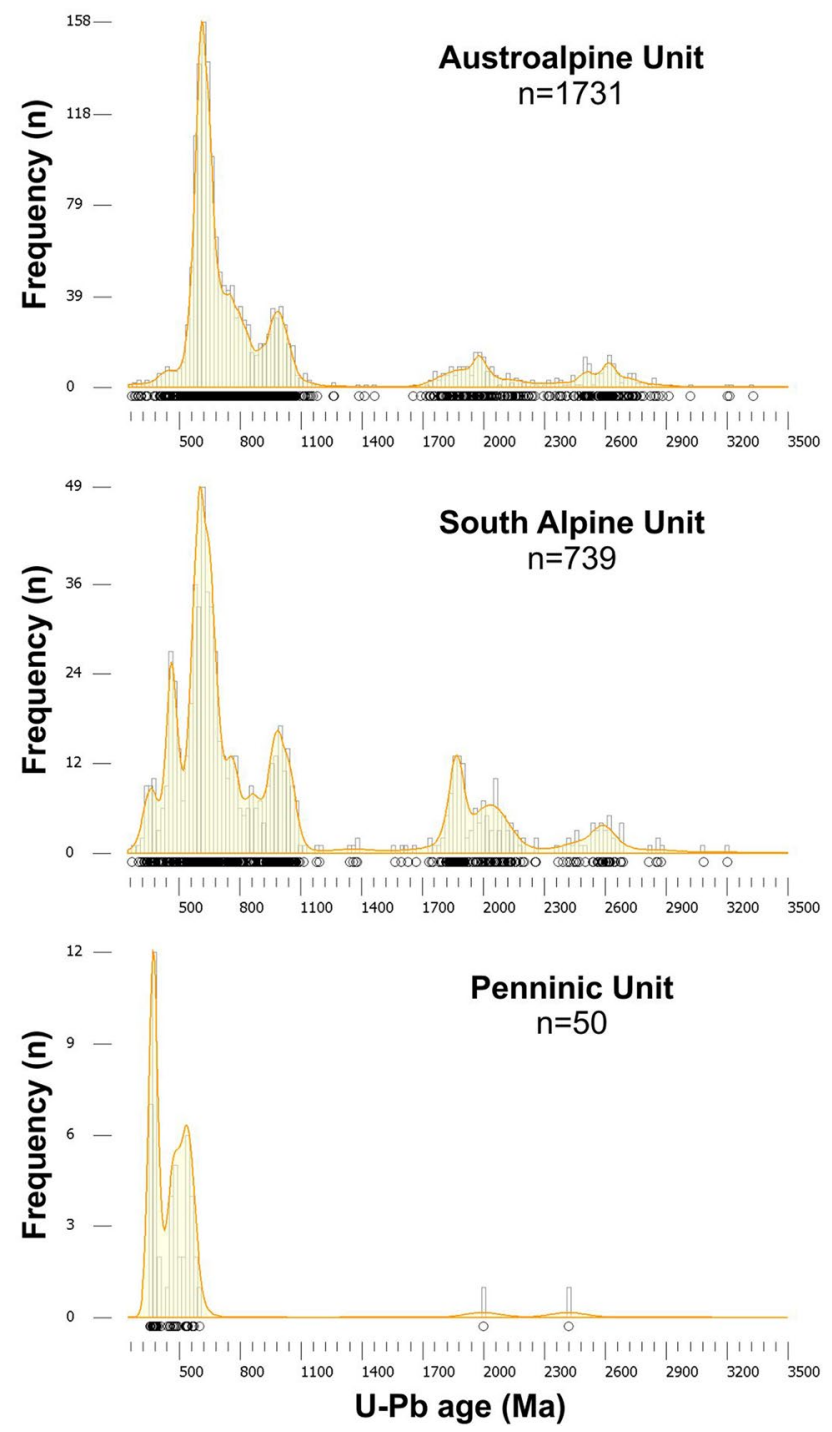

Fig. 8 Kernel density estimate curves and histograms plotted using DensityPlotter (Vermeesch 2012) for compiled U-Pb detrital zircon data of the Alpine basement (this work; Heinrichs et al. 2012; Siegesmund et al. 2018; Arboit et al. 2019). Plots only include data with $\pm 10 \%$ discordance. Bin and bandwidth $=20 \mathrm{myr}$

in terms of provenance are observed between Austroalpine and South Alpine units (Fig. 8). Most studied samples are characterized by a major peak at ca. 630-590 Ma, representing a large contribution of Late Cryogenian to Early Ediacaran magmatic sources (Table 2, Supplementary Material 4). The most likely source seem thus to be widespread Pan-African magmatism along the northern Gondwana shelf (e.g., Meinhold et al. 2011; Garfunkel 2015), most likely in the eastern segment (Siegesmund et al. 2018; Stephan et al. 2019a, b; Oriolo et al. 2021), thus accounting for Neoarchean to Paleoproterozoic basement contribution of the Saharan Metacraton (Abdelsalam et al. 2002; Liégeois et al. 2013). The paleogeographic position at the eastern segment

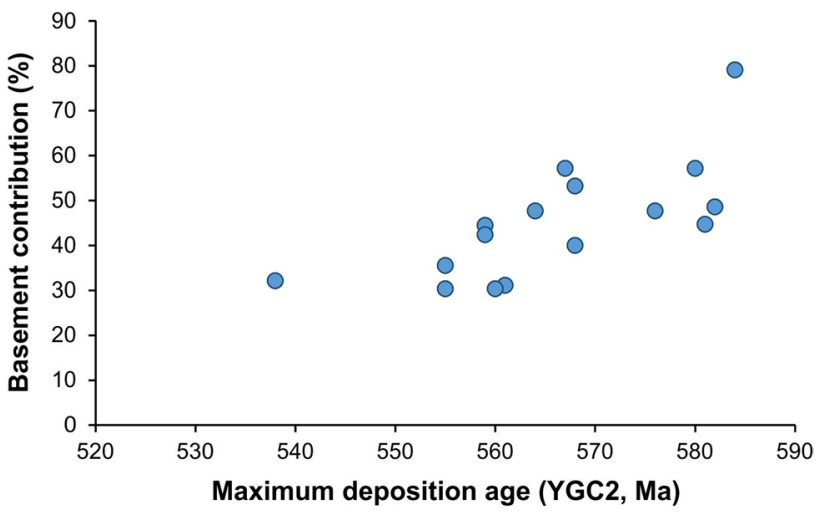

Fig. 9 Maximum deposition age vs basement contribution. For the latter, ages $>700$ Ma were considered

of the Gondwanan shelf is further supported by the characteristic Late Stenian to Early Tonian peak (ca. 1050-900 Ma; Table 2), attributed by Siegesmund et al. (2018) to derivation from Bayudian rocks exposed in the northeastern Saharan Metacraton (Küster et al. 2008; Evuk et al. 2014) and the Sinai basement at the northern Arabian-Nubian Shield (Be'eri-Shlevin et al. 2009, 2012). The youngest sequences also record a contribution of Late Ediacaran zircons, which may alternatively derive from Pan-African and/or Cadomian magmatism. Since these ages are commonly associated with Cambrian grains in a minor population at ca. $550-510 \mathrm{Ma}$, they are interpreted as the result of Cadomian sources, though the contribution of late Pan-African magmatism is also likely. Similarly to Cadomian sources, minor Ordovician to Early Silurian (ca. 480-430 Ma) and Devonian-Carboniferous (ca. 370-330 Ma) peaks in youngest samples are attributed to local, possibly intrabasinal sources (Sect. 5.2).

Similar results were also obtained for further coeval Late Ediacaran to Early Devonian Austroalpine (i.e., NorthernDefereggen Petzeck Group, Defereggen Group, Thurntaler Phyllite Group and Gailtal Metamorphic Basement) and South Alpine (i.e., Val Visdende Formation) metasedimentary sequences (Heinrichs et al. 2012; Siegesmund et al. 2018; Arboit et al. 2019). Furthermore, Siegesmund et al. (2018) also suggested a correlation between the Thurntaler Phyllite Group and the Val Visdende Formation, reinforcing similarities between Austroalpine and South Alpine units.

Though all samples show similar age peaks (Supplementary Material 4), a comparison of maximum sedimentation ages and relative basement contribution, attributed to prePan-African ( $>700 \mathrm{Ma}$ ) sources, shows a general decrease for younger ages (Fig. 9). This may imply that younger sequences might have not only incorporated younger Paleozoic magmatic sources but also received less input from basement rocks. Hence, the contribution of the latter may have not resulted from direct erosion of cratonic sources by first-order sediments but, instead, from reworking of 
previous (meta)sedimentary units already containing basement-derived detrital zircons, which is further supported by geochemical evidence documenting significant recycling (Figs. 2b, 3a, c; Sect. 4.2). For instance, Ordovician sequences might have received detritus from erosion of Cadomian belts comprising both Late Ediacaran to Cambrian magmatism and sedimentary sequences that already contain basement-derived zircons, thus accounting for the observed detrital zircon patterns (see also Sect. 5.2).

In contrast to Austroalpine and South Alpine sequences, Penninic rocks of the Tauern Window Basement show a different zircon pattern, with only 2 out of 50 concordant zircons yielding pre-Ediacaran, Paleoproterozoic ages. These ages are attributed to northern Gondwana basement rocks, together with Pan-African contributions related to the group of ca. 580-550 Ma. Similar results were also reported for Early Paleozoic metasedimentary rocks of the SiviezMischabel nappe (Scheiber et al. 2014). Likewise, Cadomian magmatism seems to be the most likely source of the main peak at ca. 530-510 Ma, whereas younger, comparable intrabasinal sources are also inferred for Ordovician and Early Devonian grains. Therefore, the Tauern Window Basement might have been located along the northern Gondwana margin during the Early to Middle Paleozoic but, most likely, was part of the western part of the shelf (sensu Stephan et al. 2019a; see Sect. 5.2 for further details).

\section{Tectonic and paleogeographic implications}

During the late stages of Pan-African collisional events, the northern Western Gondwana margin records Late Ediacaran subduction along the Cadomian Orogen. The Cadomian Belt represented a retreating accretionary orogen recording widespread arc magmatism associated with a major flare-up event at ca. 580-520 Ma, back-arc basins and a main tectonometamorphic peak at ca. 550-540 Ma (Figs. 10, 11; Peucat 1986; Zulauf et al. 1999; Dörr et al. 2002; Linnemann et al. 2007,
2014; Garfunkel 2015; von Raumer et al. 2015; Moghadam et al. 2017, 2019; Dörr and Stein 2019; Oriolo et al. 2021).

In the Austroalpine Unit, the Cadomian magmatic arc record is well-recorded in the Ediacaran to Cambrian Northern-Defereggen-Petzeck Group (Schulz et al. 2008 and references therein). Metasedimentary rocks of the Prijakt Subgroup are intercalated with eclogitic amphibolites with $\mathrm{N}-\mathrm{MORB}$ geochemical signature and $\mathrm{Pb}-\mathrm{Pb}$ evaporation age of ca. $590 \mathrm{Ma}$, whereas arc-related hornblende-bearing orthogneisses yielding $\mathrm{Pb}-\mathrm{Pb}$ evaporation ages of ca. 551-533 Ma are recorded in both Prijakt and Rotenkogel Subgroups (Schulz and Bombach 2003; Schulz et al. 2004). Coeval calc-alkaline metagabbros and metatonalites with U-Pb TIMS zircon ages of ca. 568-522 Ma were reported for the Silvretta Nappe, whereas alkaline granitic orthogneisses yielded slightly younger U-Pb TIMS and $\mathrm{Pb}-\mathrm{Pb}$ evaporation zircon ages of ca. 526-519 Ma (Müller et al. 1995; Schaltegger et al. 1997). On the other hand, coeval arc magmatism is recorded by calc-alkaline gabbroic to dioritic gneisses yielding U-Pb LA-ICP-MS zircon ages of ca. 544-533 Ma in the Maggia and Sambuco nappes of the Penninic Unit (Bussien et al. 2011). The latter are also coeval with protolith crystallization of orthogneisses and minor amphibolites and metagabbros in the Tauern Window basement, constrained at ca. 551-507 Ma by U-Pb SHRIMP and LA-ICP-MS zircon data (Eichhorn et al. 1999, 2001; Veselá et al. 2008).

The widespread occurrence of Late Ediacaran to Cambrian calc-alkaline arc-related magmatism indicates a comparable arc position for most Alpine basement domains, though the local presence of mafic magmatism reveals the presence of back-arc relics as well (Fig. 11; Müller et al. 1995; Eichhorn et al. 2001; Schulz et al. 2008). The arc and back-arc settings are also supported by whole-rock geochemical data, which also revealed recycling and dominance of felsic arc-related sources (Sect. 4.2). Reworking of older Pan-African sequences may account for the latter, as
Fig. 10 Sketch showing the position of the Alpine basement domains during the Cadomian orogeny (modified after Eichhorn et al. 2001; Siegesmund et al. 2018; Žák and Sláma 2018). Western vs eastern provenance sensu Stephan et al. (2019a)

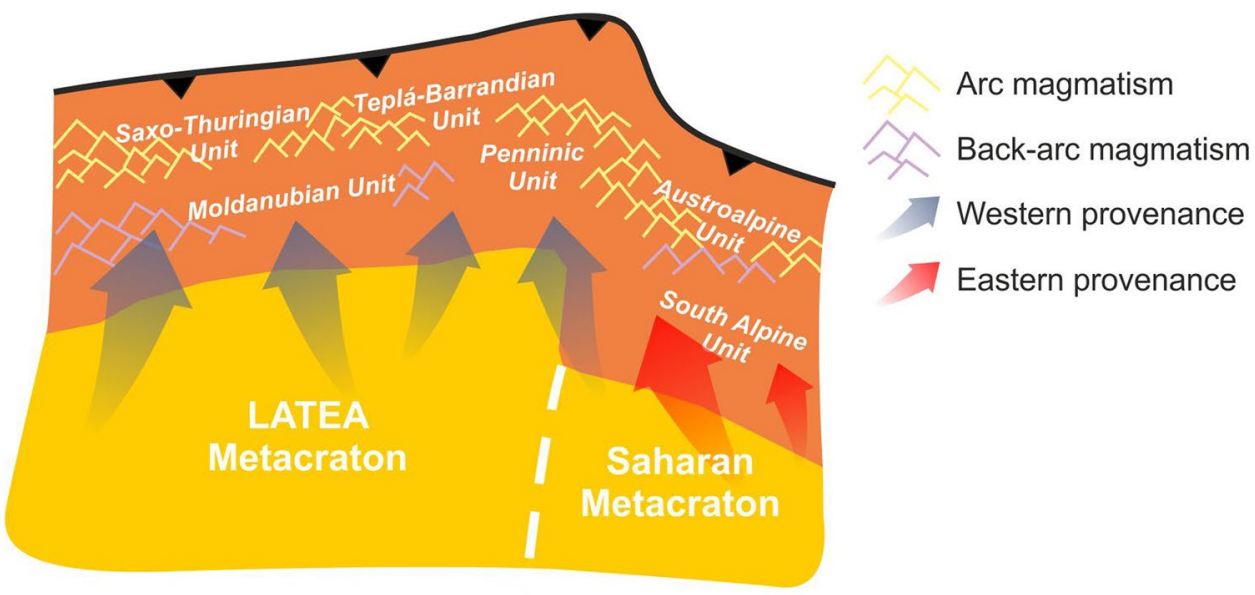



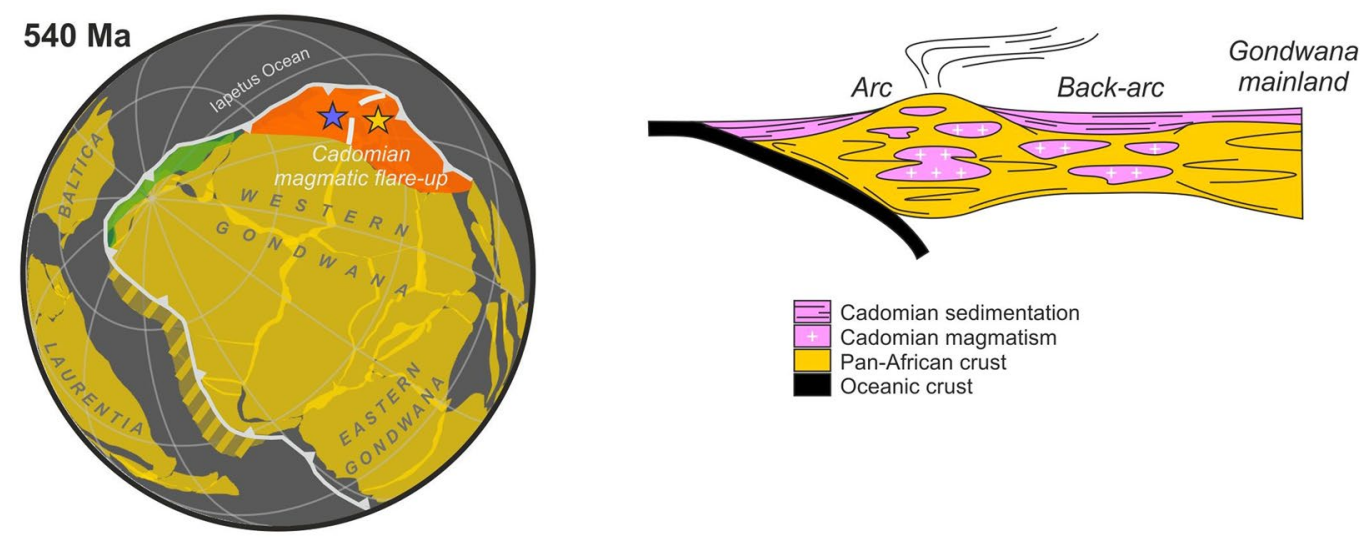

Cadomian sedimentation

Cadomian magmatism

Pan-African crust

Oceanic crust
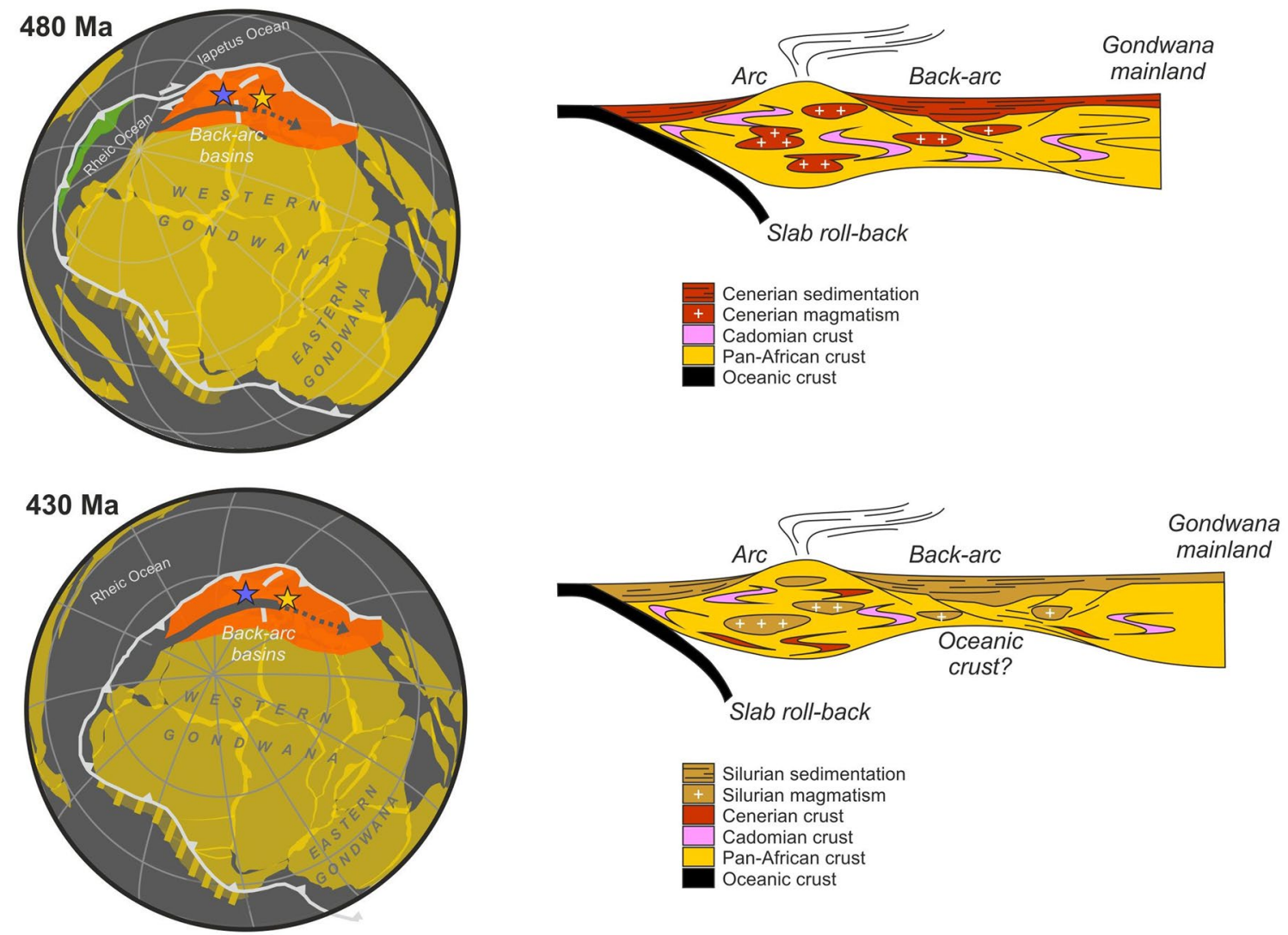

Cenerian sedimentation

Cenerian magmatism

Cadomian crust

Pan-African crust

Oceanic crust

Fig. 11 Schematic paleogeographic and tectonic evolution of Alpine basement domains (modified after Schulz et al. 2004, 2008; Siegesmund et al. 2018; Oriolo et al. 2021). Paleogeographic reconstructions based on the database of Scotese (2016) were made using GPlates 2.2 (Müller et al. 2018). Blue and yellow stars represent the location of the Penninic and Austroalpine/South Alpine Units, respec-

suggested by geophysical data revealing a Cadomian structural grain overprinting the Pan-African margin of northern Africa (Brahimi et al. 2018 and references therein). In addition, alkaline granites are attributed to the post-orogenic Cadomian phase (Müller et al. 1995). Despite their common tectonic setting, Alpine basement domains show a major contrast in the sedimentary provenance pattern, most likely tively, in the western and eastern parts of the shelf (sensu Stephan et al. 2019a). The pre-Variscan evolution shows the protracted evolution of a dominantly retreating-mode accretionary orogen, which was developed along a Pan-African basement that progressively incorporates Paleozoic crust due to recycling and minor juvenile input. See Sect. 5 for further details

resulting from differences in terms of paleogeography. The detrital record of the Austroalpine and South Alpine Units shows a clear affinity with the eastern part of the margin, whereas the Penninic Unit was most likely located along the western segment (Siegesmund et al. 2018; Stephan et al. 2019a, b; Oriolo et al. 2021). The lack of Cadomian magmatism in the South Alpine Unit, reinforced by the pre-Alpine 
palinpastic reconstruction (Fig. 1c; see also Eichhorn et al. 2001), suggests a possible retroarc foreland position regarding the Austroalpine Unit, at least for the Ediacaran-Cambrian (Fig. 10). For the Penninic Unit, the presence of Late Devonian Variscan metamorphism, also recorded by sample TAUF-1, together with the Early to Late Paleozoic magmatic record, suggests a paleogeographic position close to the Moldanubian Unit of the Bohemian Massif (Fig. 10; Eichhorn et al. 2001; Bergomi et al. 2018). This correlation is further supported by similarities in the detrital zircon pattern of Early to Middle Paleozoic Penninic metasedimentary rocks and that of coeval Moldanubian sequences (Košler et al. 2014). Considering the reconstruction of Žák and Sláma (2018) for the Bohemian Massif, the Penninic Unit was possibly located between Gondwana mainland and the Moldanubian Unit, whereas the Saxo-Thuringian and TepláBarrandian Units were placed to the north (i.e., trenchwards) of the latter. This configuration (Fig. 10) is further supported by relics of a forearc accretionary complex in the TepláBarrandian Unit (Hajná et al. 2013, 2017).

After the Late Cambrian Cadomian post-orogenic record (e.g., Dörr et al. 2002), the Ordovician is characterized by the Cenerian Orogeny, which is also associated with subduction along a retreating accretionary orogen (Fig. 11; Zurbriggen 2015, 2017; Oriolo et al. 2021). Though this event is nearly ubiquitously recorded in European Cadomian domains (Stephan et al. 2019a and references therein), the Alpine region is a key locality (Zurbriggen 2017 and references therein), since it hosts a vast record of coeval Ordovician metamorphism, magmatism and sedimentation. In the Austroalpine basement, migmatites of the Ötztal-Stubai Complex record high-temperature/low-pressure metamorphism at ca. $670-750{ }^{\circ} \mathrm{C}$ and $<2.8 \mathrm{kbar}$ (Thöny et al. 2008). EPMA Th-U-Pb monazite ages reveal Silurian partial melting mostly at ca. $441 \mathrm{Ma}$ (Thöny et al. 2008; Rode et al. 2012), whereas Ordovician anatexis is supported by $\mathrm{Pb}-\mathrm{Pb}$ evaporation and U-Pb TIMS zircon data at ca. 490-485 Ma (Klötzli-Chowanetz et al. 1997). In contrast, a U-Pb TIMS zircon age of ca. 478 Ma provides a maximum age for highpressure metamorphism in the Aar Massif of the Helvetic Unit, succeeded by high-temperature metamorphism and anatexis at ca. 456-445 Ma (Schaltegger 1993; Schaltegger et al. 2003). In a similar way, eclogite facies metamorphism under ca. $740-680{ }^{\circ} \mathrm{C}$ and $23.5-18.5 \mathrm{kbar}$ is constrained at ca. $457-448 \mathrm{Ma}$ by U-Pb TIMS ages of metamorphic zircon and rutile in the Strona-Ceneri Zone of the South Alpine Unit, followed by Barrovian metamorphism at ca. $630-570{ }^{\circ} \mathrm{C}$ and $7-9 \mathrm{kbar}$ (Franz and Romer 2007). In addition, Ordovician deformation is constrained between ca. 494 and $467 \mathrm{Ma}$ in the southernmost Penninic Unit, as indicated by U-Pb LA-ICP-MS and TIMS zircon ages of pre- and post-deformation magmatic rocks (Maino et al. 2019 and references therein).
In the Austroalpine Unit, Ordovician felsic magmatism is also well-documented by dominantly peraluminous calc-alkaline orthogneisses and metaporphyroids yielding $\mathrm{Pb} / \mathrm{Pb}$ evaporation and $\mathrm{U}-\mathrm{Pb}$ SHRIMP ages of ca. 477-448 Ma, associated with metasedimentary sequences such as the Innsbruck Quartzphyllite Complex, NorthernDefereggen-Petzeck Group, Defereggen Group and Thurntaler Phyllite Group (Schulz and Bombach 2003; Schulz et al. 2004, 2008; Siegesmund et al. 2007; Blatt 2013; Tropper et al. 2016). Comparable felsic porphyroids yielding U-Pb TIMS and $\mathrm{Pb}-\mathrm{Pb}$ evaporation zircons ages of ca. 485-479 Ma are also intercalated with Comelico phyllites (Meli and Klötzli 2001), being thus coeval with the crystallization age of $479 \pm 3$ Ma obtained for the orthogneiss of Ötztal-Stubai Complex (Fig. 6b), whereas two distinct Ordovician pulses of felsic volcanic/subvolcanic activity at ca. 474-472 and 454-452 Ma are well-documented by U-Pb LA-ICP-MS zircon data of the South Alpine Basement (Arboit et al. 2019). On the other hand, the Silvretta-Seckau Nappe System host peraluminous metagranitoids with $\mathrm{U}-\mathrm{Pb}$ LA-ICP-MS zircon ages of ca. 508-486 Ma (Mandl et al. 2018). Similar results were reported for the Penninic Unit, with orthogneisses yielding U-Pb LA-ICP-MS zircon ages of ca. 505 and $482 \mathrm{Ma}$ in the Siviez-Mischabel nappe basement (Scheiber et al. 2014) and slightly younger peraluminous orthogneisses with U-Pb LA-ICP-MS zircon ages of ca. 485-467 in the Maggia and Sambuco nappes (Bussien et al. 2011). Comparable high-K to shoshonitic peraluminous granitoids yielding $\mathrm{U}-\mathrm{Pb}$ SHRIMP zircon ages of ca. 465-456 are exposed in the Grand St Bernard-Briançonnais nappe system (Bergomi et al. 2018), whereas U-Pb LA-ICPMS zircon data of the Adula nappe reveals mafic magmatism at ca. 521-515 and $445 \mathrm{Ma}$, together with felsic peraluminous intrusions at ca. 459-445 Ma (Cavargna-Sani et al. 2014). In the southernmost Penninic Unit, felsic volcanic and plutonic activity is well-constrained at ca. 507-446 Ma by U-Pb SHRIMP, LA-ICP-MS and TIMS zircon data (Maino et al. 2019), whereas a U-Pb LA-ICP-MS zircon age of ca. 468 Ma was obtained for basic magmatism (Giacomini et al. 2007). Finally, in the Argentera Massif of the Helvetic Unit, crystallization of metabasic and metadacitic rocks is constrained at ca. 457 and $443 \mathrm{Ma}$, respectively, by U-Pb SHRIMP zircon ages (Rubatto et al. 2001), being thus slightly younger than U-Pb LA-ICP-MS zircon ages of ca. 464-455 Ma of metabasic rocks and orthogneisses of the Aiguilles Rouges Massif (Bussy et al. 2011).

On the other hand, detrital zircon data of coeval Late Cambrian to Ordovician sedimentation in all Alpine domains indicates that Cadomian rocks also contributed to detritus (Sect. 5.1; Neubauer et al. 2001; Heinrichs et al. 2012; Scheiber et al. 2014; Siegesmund et al. 2018; Arboit et al. 2019), suggesting relatively proximal sources. Since the Cadomian arc, in turn, reworked Pan-African sequences, 
the presence of recycling processes in Ordovician sedimentary sequences may thus suggest that pre-Cadomian zircons possibly derived from Cadomian (meta)sedimentary rocks, though detritus from direct erosion of the pre-Cadomian basement might have also contributed to some extent. Likewise, geochemical data of metasedimentary rocks also support the presence of a retreating accretionary orogen, indicated by the mixed arc and back-arc signatures (Figs. 2c, 3, 4d; Sect. 4.2).

In contrast to widespread Cambrian-Ordovician units, the Silurian to Early Devonian tectonomagmatic record is rather scarce. In the Austroalpine Unit, alkaline basalts intercalated with metasedimentary rocks of the NorthernDefereggen-Petzeck Group yielded a $\mathrm{Pb}-\mathrm{Pb}$ zircon evaporation age of ca. $430 \mathrm{Ma}$ (Schulz and Bombach 2003). Slightly younger high-pressure metamorphism is recorded in the Tauern Window, as indicated by U-Pb TIMS/LA-ICP-MS zircon and Sm-Nd garnet-whole-rock isochrone data of ca. 422-415 Ma (von Quadt et al. 1997). Comparable eclogitefacies metamorphism is also constrained at ca. $420-350 \mathrm{Ma}$ by U-Pb LA-ICP-MS and SHRIMP data of zircon metamorphic rims at the southernmost Penninic Unit (Maino et al. 2019). Further evidence of Silurian to Early Devonian magmatism and metamorphism is also indicated by detrital zircon data (Table 1; Supplementary Material 4; Arboit et al. 2019). Finally, Late Ordovician to Silurian high-temperature metamorphism at peak conditions of ca. $800{ }^{\circ} \mathrm{C}$ and $6 \mathrm{kbar}$ is also documented by EPMA Th- $\mathrm{U}-\mathrm{Pb}$ monazite ages of ca. 445-438 Ma of the Helvetic Aiguilles Rouges Massif (Schulz and von Raumer 2011).

The Silurian to Early Devonian evolution seems to be a continuation of previous Ordovician tectonic processes, characterized by a magmatic arc with associated crustal extension leading to an anomalously high thermal gradient (Schulz and von Raumer 2011). This is supported by the presence of both alkaline and arc-related magmatism, together with high-pressure and low-pressure/high-temperature metamorphism (von Quadt et al. 1997; Schulz and Bombach 2003; Schulz and von Raumer 2011). Since Ordovician back-arc evolution shows an eastward propagation of crustal extension along the Cadomian margin (von Raumer et al. 2015; Cambeses et al. 2017; Stephan et al. 2019a; Oriolo et al. 2021), it may thus be possible that the eastern part of the shelf was affected by this event first at ca. $430 \mathrm{Ma}$, as indicated by alkaline magmatism of the Austroalpine Unit. On the other hand, the scarcity of calc-alkaline magmatism related to the arc may also suggest a possible change in regional tectonic processes, from retreating- to advancingmode subduction related to the onset of Variscan events by the Middle to Late Devonian (see below).

The Middle Devonian to Carboniferous evolution of the Alpine basement is intimately related to the onset of Variscan tectonometamorphic processes. Arc-related magmatism resumed, as indicated by calc-alkaline granitoids yielding U-Pb SHRIMP and LA-ICP-MS zircon ages of ca. 374-331 Ma (Eichhorn et al. 2000; Veselá et al. 2010) in the Tauern Window and ca. 371-369 Ma in the Grand St Bernard-Briançonnais nappe system of the Penninic Unit (Bergomi et al. 2018). In the Graywacke Zone of the Austroalpine Unit, mafic metatuffs yielding a U-Pb LA-ICPMS zircon age of ca. $385 \mathrm{Ma}$ (Dum et al. 2012). In addition, the Variscan collision is well-documented in several areas by the occurrence of high-pressure metamorphism, suggesting a generally eastward younging trend. In the Penninic Unit, U-Pb LA-ICP-MS zircon ages indicate eclogitefacies metamorphism at ca. 392-376 Ma for the Ligurian Alps (Giacomini et al. 2007), being thus comparable with the age of metamorphism obtained for sample TAUF-1 (Fig. 6c), whereas U-Pb SHRIMP ages of ca. 376-329 Ma were reported for the Adula Nappe (Liati et al. 2009). In the Argentera Massif of the Helvetic Unit, U-Pb SHRIMP ages of ca. 341-336 Ma constrain the timing of high-pressure metamorphism (Rubatto et al. 2010), and are comparable to those of the Austroalpine Unit, which are constrained at ca. 373-342 Ma in the Ötztal-Stubai Complex (Sm-Nd mineral isochron data; Miller and Thöni 1995), ca. 336-325 in the Tonale Nappe ( $\mathrm{Sm}-\mathrm{Nd}$ mineral isochron data; Tumiati et al. 2003) and ca. 321-300 Ma in the basement south of the Tauern Window (EPMA Th-U-Pb monazite data; Krenn et al. 2012; Lu-Hf garnet data, Hauke et al. 2019).

In line with the aforementioned data, zircons of the Hochwipfel Formation record the development of a Late Devonian to Early Carboniferous magmatic arc with moderate contributions from depleted mantle sources in the northern hinterland of the future flysch basin. This magmatism is nearly coeval with the early Variscan granite magmatism recorded in the Tauern Window (Eichhorn et al 2000; Veselá et al. 2010), attributed to the Late Devonian onset of convergence with Laurussia. Similarly, sedimentological evidence of the southern platform sequences of the Carnic Alps records an increasing subsidence since the Frasnian, possibly resulting from tectonic causes (Pondrelli et al. 2015). The magmatic and sedimentological record can thus be linked to the subduction of an oceanic basin starting in the Late Devonian during Variscan convergence (Läufer et al. 2001).

The provenance of Silurian to Carboniferous metasedimentary sequences is comparable to those of the Early Paleozoic age and also shows recycling. However, they record contributions of Cadomian, Cenerian and SilurianCarboniferous intrabasinal sources as well (Supplementary Material 4; Mader et al. 2007; Lerchbaumer et al. 2010), thus explaining the dominant felsic geochemical fingerprint of the source, though the latter may also result from mixing of older sequences. Intrabasinal sources may also account for the ambiguous detrital vs metamorphic origin of some zircon crystals (e.g., Table 1), possibly deriving from local 
high-grade metamorphic rocks, such as those of the Ötztal-Stubai Complex. Likewise, these sequences are coeval with subduction but are also related to back-arc extension, particularly during the Silurian (e.g., Schulz et al. 2008; Bergomi et al. 2018; Arboit et al. 2019). Already by the Late Carboniferous, all Alpine domains underwent the Variscan collision, thus leading to widespread post-collisional tectonomagmatic and metamorphic processes (e.g., Neubauer et al. 1999; Läufer et al. 2001; von Raumer et al. 2003, 2009; Schulz et al. 2008; Kunz et al., 2018).

In spite of minor differences, Alpine basement units seem thus to record a common Ediacaran to Paleozoic tectonic history, as indicated by similarities in their sedimentary, magmatic and metamorphic record. Excepting for the minor contribution of local Paleozoic intrabasinal magmatic sources, they exhibit a comparable detrital zircon fingerprint that reflects a clear affinity with the Western Gondwana northern margin (Fig. 8). In this sense, the Alpine basement remain attached to the Gondwana mainland during the entire Paleozoic, similarly to other Cadomian domains such as the Bohemian, Iberian, Armorican and Serbo-Macedonian Massifs (Murphy et al. 2006; Blatt 2013; Pastor-Galán et al. 2013; Gutiérrez-Alonso et al. 2015; Antić et al. 2016; Žák and Sláma 2018; Romer and Kroner 2019; Stephan et al. 2019a; Oriolo et al. 2021). This is particularly relevant for the interpretation of Silurian-Devonian evolution, commonly attributed to the opening of the Paleotethys Ocean (Stampfli 2000; Stampfli et al. 2002; von Raumer et al. 2013; Maino et al. 2019). The presence of local alkaline mafic magmatism (Schulz and Bombach 2003), together with the Gondwanan detrital affinity of Silurian-Devonian metasedimentary sequences, indicates the opening of a minor backarc basin, instead of the development of large volumes of oceanic crust. This is in line with reconstructions of Stampfli et al. (2011) for ca. 440-420 Ma, which suggest a possible Devonian development of the Paleotethys in the back-arc region of the Alpine basement. However, no clear evidence of Devonian oceanic crust has been so far reported in the Alps and subduction is clearly documented at least since the Late Devonian (see above). In the Carnic Alps, the arguably subducted basin may be recorded by shelf sequences only with scarce intraplate alkaline basalts (i.e., Raabtal; Läufer et al. 2001 and references therein). Even when present in adjacent regions such as the Western Carpathians, ophiolites only comprise minor bodies with a geochemical fingerprint that suggests an association with a continental margin (Ivan and Méres 2015), thus implying a relatively minor oceanic basin. Neither the Rheic nor the Paleotethys oceanic crust might have thus developed in the back-arc of the Alpine basement and adjacent tectonostratigraphic domains, at least not in the context of a large basin. Early to Middle Paleozoic oceanic basins between the proto-Alps and Gondwana mainland were thus of limited extension, as further supported by paleontological and paleobiogeographical constraints (Jansen 2012, 2016). Therefore, their pre-Variscan Cambrian to Devonian tectonic evolution seem to record a continuum related to a protracted retreating-mode accretionary orogen, with diachronous back-arc basin opening and possibly discrete compressional/transpressional pulses linked to changing subduction zone dynamics.

In terms of tectosedimentary dynamics, Early to Middle Paleozoic sedimentation was mainly controlled by a general thinning of the continental crust due to crustal extension/ transtension and associated subsidence (e.g., Loeschke and Heinisch 1993; Schönlaub and Histon 2000), as supported by similarities in the major and trace element composition of all studied sequences, which may alternatively result from the aforementioned recycling processes. The proto-Alpine Paleozoic accretionary orogen was characterized by a relatively short timespan between sedimentation and subsequent metamorphism, indicating relatively rapid deformation and exhumation (Table 1; Mader et al. 2007; Cavargna-Sani et al. 2014; Zurbriggen 2017; Oriolo et al. 2021), as also documented in adjacent regions (e.g., Dörr and Stein 2019). Likewise, the common presence of intrabasinal magmatism, together with evidence of recycling of adjacent (meta)sedimentary rocks and moderate sediment maturity (Sect. 4.2), thus points to relatively proximal sources (Cavargna-Sani et al. 2014; Siegesmund et al. 2018).

\section{Crustal growth}

Figure $7 \mathrm{~b}$ summarizes $\mathrm{Lu}-\mathrm{Hf}$ data of Neoproterozoic to Paleozoic detrital zircons of the Alps (Supplementary Material 5; Chu et al. 2016; Siegesmund et al. 2018), which are also comparable for all Alpine basement units, similarly to the $\mathrm{U}-\mathrm{Pb}$ detrital zircon age pattern (Fig. 8). Zircons with Pan-African ages between ca. 650 and 580 Ma show variable suprachondritic to subchondritic $\varepsilon_{\mathrm{Hf}}$ values. Late Ediacaran ages of ca. 580-550 Ma, attributed to either late Pan-African or early Cadomian sources, show variable $\varepsilon_{\mathrm{Hf}}$ values between ca. -11 and +8 . This variable signature indicates the contribution of both depleted mantle and continental crustal sources, as recorded in northeastern Africa (Siegesmund et al. 2018). Pan-African juvenile magmatism is typical in the Arabian-Nubian Shield, whereas coeval magmatism of the Saharan Metacraton is dominated by a large contribution of continental crustal sources due to significant crustal reworking (e.g., Abdesalam et al. 2002; Küster et al. 2008; Liégeois and Stern 2010; Liégeois et al. 2013; Oriolo et al. 2017).

Though scarce in metasedimentary basement rocks, Late Ediacaran to Paleozoic zircons are well-documented in Cretaceous to Cenozoic Alpine units and define a clear isotopic array towards subchrondritic $\varepsilon_{\mathrm{Hf}}$, with two main Orodovician and Carboniferous-Permian clusters attributed to Cenerian 
and Variscan tectonomagmatic processes (Chu et al. 2016). Based on this trend, Chu et al. (2016) argued that Late Ediacaran to Late Paleozoic magmatism mostly implied reworking of older crustal sources and negligible juvenile crustal addition. Lu-Hf $T_{\mathrm{DM}}$ model ages would imply reworking of Late Paleoproterozoic to Early Mesoproterozoic basement rocks (Supplementary Material 5; Chu et al. 2016), which are nearly absent in the northern African basement, and the Alpine basement and detrital zircon record (Fig. 8; Schulz 2008; Chu et al. 2016). Therefore, the most likely explanation to account for such Lu-Hf isotopic array is to consider reworking of a Pan-African basement resulting from mixing of both juvenile and crustal sources (see below). In addition, minor juvenile input seems also evident during Cadomian, Cenerian and Variscan flare-up magmatic events (Fig. 7b), further supported by $\mathrm{Sm}-\mathrm{Nd}$ and $\mathrm{Rb}-\mathrm{Sr}$ data of Paleozoic magmatic units (Müller et al. 1995; Schaltegger et al. 1997; Schulz et al. 2004). Protracted subduction giving rise to a dominantly retreating accretionary orogeny that culminated with the Variscan collision may thus satisfactorily explain this isotopic evolution (Sect. 5.2). In this context, the input of mantle-derived magmas mixed with (meta)sedimentary sources took place in the arc and back-region, as further supported by $\mathrm{Lu}-\mathrm{Hf}$ data of different northern peri-Gondwanan domains, which show a clear contribution of depleted mantle sources for both Cadomian and Cenerian magmatism (Oriolo et al. 2021 and references therein). Particularly for the Ordovician, this is also in line with the common occurrence of peraluminous magmatism, indicative of assimilation or anatexis of (meta)sedimentary rocks, which is further reinforced by the presence of inherited Proterozoic to Cambrian zircon xenocrysts (Sect. 4.3; Schulz and Bombach 2003; Schulz et al. 2004, 2008; Siegesmund et al. 2007; Bussien et al. 2011; Cavargna-Sani et al. 2014; Bergomi et al. 2018; Mandl et al. 2018; Neubauer et al. 2020).

As previously mentioned, the Paleozoic isotopic evolution of the Alps is intimately related to its Precambrian basement. So far, the Alpine basement has been essentially attributed to Pan-African metasedimentary and metaigneous rocks (Schaltegger et al. 1997; Schulz 2008; Schulz et al. 2008; Siegesmund et al. 2018), being the oldest magmatic record scarce metaigneous rocks with U-Pb TIMS zircon ages of ca. 670-603 Ma (Gebauer et al. 1992; von Quadt 1992; Schaltegger et al. 1997; Korikovsky et al. 1998). Gebauer et al. (1988) also reported a U-Pb zircon age of ca. $870 \mathrm{Ma}$ for an eclogite protolith, which would also suggest the presence of Early Neoproterozoic relics, in a similar way to other Cadomian domains (Zlatkin et al. 2014, 2017; Dörr et al. 2015; Hanžl et al. 2019). Therefore, the Alpine basement seems to lack in pre-Neoproterozoic cratonic/metacratonic roots and may derive mainly from Pan-African crust developed at the margin of northwestern Gondwana.
The dominance of a Pan-African basement in the Alps is further supported by geochemical and geochronological data of Paleozoic metasedimentary sequences, such as recycling processes in the oldest Cadomian metasedimentary sequences and the large contribution of Pan-African zircons (Sect. 4.1, Heinrichs et al. 2012; Siegesmund et al. 2018). Further evidence is provided by the $\mathrm{Lu}-\mathrm{Hf}$ crustal array, implying reworking of Late Paleoproterozoic to Early Mesoproterozoic rocks, as indicated by $T_{\mathrm{DM}}$ model ages (Supplementary Material 5; Chu et al. 2016). Siegesmund et al. (2018) obtained comparable Sm-Nd whole-rock $T_{\mathrm{DM}}$ values for Late Ediacaran to Early Paleozoic metasedimentary sequences, thus indicating that Late Paleoproterozoic to Early Mesoproterozoic model ages may actually represent bulk values resulting from mixing. As a corollary, it is inferred that the Alpine basement essentially comprises Pan-African metasedimentary and minor metaigneous rocks, which were significantly reworked during the protracted Paleozoic orogenic evolution (see also Sect. 5.2).

\section{Final remarks}

Detrital zircon data reveal protracted Late Ediacaran to Carboniferous tectosedimentary processes prior to the Variscan collision. In the case of Austroalpine and South Alpine units, no major differences in terms of provenance are observed, since most detrital zircon samples are characterized by a major Pan-African peak, together with Late Stenian to Cryogenian zircons and minor Neoarchean to Paleoproterozoic contributions. Their detrital zircon spectra thus point to a source located in the northeastern Saharan Metacraton and the Sinai basement at the northern Arabian-Nubian Shield, whereas the Penninic Unit might have been placed further west, close to the Moldanubian Unit of the Bohemian Massif. However, it is evident that all Alpine basement remains were attached to Gondwana mainland during the entire Paleozoic, in line with evidence of the adjacent Bohemian, Iberian and Armorican Massifs.

The Late Ediacaran to Silurian tectonic evolution, which includes Cadomian and Cenerian tectonometamorphic and magmatic processes, seems thus to record a continuum related to a dominantly retreating-mode accretionary orogen, with diachronous back-arc basin opening and possibly discrete compressional/transpressional pulses linked to changes in subduction zone dynamics. Though unclear, the relative scarcity of calc-alkaline arc-related igneous rocks could be attributed to a magmatic lull resulting from a possible regional geodynamic change, from retreating- to advancingmode subduction related to the onset of Variscan events by the Middle to Late Devonian. By the Late Carboniferous, all Alpine domains underwent the Variscan collision, thus 
leading to widespread post-collisional tectonomagmatic and metamorphic processes.

In terms of tectosedimentary processes, the proto-Alpine Paleozoic orogenic record is characterized by a relatively short timespan (ca. 30-10 My) between sedimentation and subsequent metamorphism, indicating relatively rapid deformation and exhumation. Likewise, evidence of intrabasinal magmatism, recycling of adjacent (meta)sedimentary rocks and moderate sediment maturity, points to relatively proximal sources.

Finally, the Alpine basement seems to comprise mostly Pan-African metasedimentary and minor metaigneous rocks, though very few Early Neoproterozoic relics might have been present as well. This Pan-African basement was significantly recycled during the protracted Paleozoic orogenic evolution, due to anatexis and/or assimilation by mantlederived magmatism. In this sense, the nearly continuous subduction during the Paleozoic implied mixing of both juvenile magmas and crustal reworking, indicating crustal growth to some extent.

Supplementary Information The online version contains supplementary material available at https://doi.org/10.1007/s00531-021-02019-7.

Acknowledgements Jan-Peter Duda and Silvana Geuna are greatly acknowledged for the support with paleontological evidence and paleogeographic reconstructions, respectively. The thin sections from the samples used for SEM Automated Mineralogy were prepared by Andreas Bartzsch and Roland Würkert at the Helmholtz Institute Freiberg for Resource Technology. The authors also wish to thank critical reviews from Franz Neubauer and Wolfgang Dörr.

Funding Open Access funding enabled and organized by Projekt DEAL.

Open Access This article is licensed under a Creative Commons Attribution 4.0 International License, which permits use, sharing, adaptation, distribution and reproduction in any medium or format, as long as you give appropriate credit to the original author(s) and the source, provide a link to the Creative Commons licence, and indicate if changes were made. The images or other third party material in this article are included in the article's Creative Commons licence, unless indicated otherwise in a credit line to the material. If material is not included in the article's Creative Commons licence and your intended use is not permitted by statutory regulation or exceeds the permitted use, you will need to obtain permission directly from the copyright holder. To view a copy of this licence, visit http://creativecommons.org/licenses/by/4.0/.

\section{References}

Abdelsalam MG, Liégeois J-P, Stern RJ (2002) The Saharan Metacraton. J Afr Earth Sci 34:119-136

Antić M, Peytcheva I, von Quadt A, Kounov A, Trivić B, Serafimovski T, Tasev G, Gerdjikov I, Wetzel A (2016) Pre-Alpine evolution of a segment of the North-Gondwanan margin: Geochronological and geochemical evidence from the central Serbo-Macedonian Massif. Gondwana Res 36:523-544
Arboit F, Chew D, Visoná D, Massironi M, Sciascia F, Benedetti G, Rodani S (2019) The geodynamic evolution of the Italian South Alpine basement from the Ediacaran to the Carboniferous: was the South Alpine terrane part of the peri-Gondwana arc-forming terranes? Gondwana Res 65:17-30

Be'eri-Shlevin Y, Katzir Y, Whitehouse MJ, Kleinhanns IC (2009) Contribution of pre Pan-African crust to formation of the Arabian Nubian Shield: new secondary ionization mass spectrometry $\mathrm{U}-\mathrm{Pb}$ and $\mathrm{O}$ studies of zircon. Geology 37:899-902

Be'eri-Shlevin Y, Eyal M, Eyal Y, Whitehouse M, Litvinovsky B (2012) The Sa'al volcano-sedimentary complex (Sinai, Egypt): a latest Mesoproterozoic volcanic arc in the northern Arabian Nubian Shield. Geology 40:403-406

Benciolini L, Poli ME, Visonà D, Zanferrari A (2006) Looking inside Late Variscan tectonics: structural and metamorphic heterogeneity of the Eastern South Alpine Basement (NE Italy). Geodin Acta 19:17-32

Bergomi MA, Dal Piaz GV, Malusà MG, Monopoli B, Tunesi A (2018) The Grand St Bernard-Briançonnais nappe system and the Paleozoic inheritance of the Western Alps unraveled by zircon U-Pb dating. Tectonics 36:2950-2972

Bernhard F, Klötzli US, Thöni M, Hoinkes G (1996) Age, origin and geodynamic significance of a polymetamorphic felsic intrusion in the Ötztal Crystalline Basement, Tirol, Austria. Mineral Petrol 58:171-196

Bhatia MR, Crook KA (1986) Trace element characteristics of graywackes and tectonic setting discrimination of sedimentary basins. Contrib Mineral Petrol 92:181-193

Blatt A (2013) Geochronologische Datierung des Kellerjochgneises und der Porphyroide in der nördlichen Grauwackenzone (Tirol, Österreich). Dissertation, Martin-Luther-Universität Halle-Wittenberg

Bouvier A, Vervoort JD, Patchett PJ (2008) The Lu-Hf and Sm-Nd isotopic composition of CHUR: constraints from unequilibrated chondrites and implications for the bulk composition of terrestrial planets. Earth Planet Sci Lett 273:48-57

Boynton WV (1984) Cosmochemistry of the rare earth elements: meteorite studies. In: Henderson P (ed) Rare earth element geochemistry. Elsevier, Amsterdam, pp 63-114

Brahimi S, Liégeois J-P, Ghienne JF, Munschy M, Bourmatte A (2018) The Tuareg shield terranes revisited and extended towards the northern Gondwana margin: magnetic and gravimetric constraints. Earth Sci Rev 185:572-599

Bussien D, Bussy F, Magna T, Masson H (2011) Timing of Palaeozoic magmatism in the Maggia and Sambuco nappes and paleogeographic implications (Central Lepontine Alps). Swiss J Geosci 104:1-29

Bussy F, Péronnet V, Ulianov A, Epard JL, von Raumer J (2011) Ordovician magmatism in the external French Alps: witness of a peri-Gondwanan active continental margin. In: GutiérrezMarco JC, Rábano I, García-Bellido D (eds) The Ordovician of the World. Instituto Geológico y Minero de España, Madrid, Cuadernos del Museo Geominero, vol 14, pp 75-82

Cambeses A, Scarrow JH, Montero P, Lázaro C, Bea F (2017) Palaeogeography and crustal evolution of the Ossa-Morena Zone, southwest Iberia, and the North Gondwana margin during the Cambro-Ordovician: a review of isotopic evidence. Int Geol Rev 59:94-130

Cavargna-Sani M, Epard JL, Bussy F, Ulianov A (2014) Basement lithostratigraphy of the Adula nappe: implications for Palaeozoic evolution and Alpine kinematics. Int J Earth Sci 103:61-82

Cawood PA, Kröner A, Collins WJ, Kusky TM, Mooney WD, Windley BF (2009) Accretionary orogens through Earth history. In: Cawood PA, Kröner A (eds) Earth accretionary systems in space 
and time. Geological Society, London, Special Publications, vol 318, pp 1-36

Chu Y, Lin W, Faure M, Wang Q (2016) Detrital zircon U-Pb ages and $\mathrm{Hf}$ isotopic constraints on the terrigenous sediments of the Western Alps and their paleogeographic implications. Tectonics 35:2734-2753

Clift PD, Vannucchi P, Morgan JP (2009) Crustal redistribution, crustmantle recycling and Phanerozoic evolution of the continental crust. Earth Sci Rev 97:80-104

Cochrane R, Spikings R, Gerdes A, Winkler W, Ulianov A, Mora A, Chiaradia M (2014) Distinguishing between in-situ and accretionary growth of continents along active margins. Lithos 202:382-394

Collins WJ (2002) Nature of extensional accretionary orogens. Tectonics 21:1024

Collins WJ, Belousova EA, Kemp AI, Murphy JB (2011) Two contrasting Phanerozoic orogenic systems revealed by hafnium isotope data. Nat Geosci 4:333-337

Coutts DS, Matthews WA, Hubbard SM (2019) Assessment of widely used methods to derive depositional ages from detrital zircon populations. Geosci Front 10:1421-1435

Dickinson WR, Gehrels GE (2009) Use of U-Pb ages of detrital zircons to infer maximum depositional ages of strata: A test against a Colorado Plateau Mesozoic database. Earth Planet Sci Lett 288:115-125

Dieni I, Giordano D, Loydell DK, Sassi FP (2005) Discovery of Llandovery (Silurian) graptolites and probable Devonian corals in the Southalpine Metamorphic Basement of the Eastern Alps (Agordo, NE Italy). Geol Mag 142:1-5

Dörr W, Stein E (2019) Precambrian basement in the Rheic suture zone of the Central European Variscides (Odenwald). Int J Earth Sci 108:1937-1957

Dörr W, Zulauf G, Fiala J, Franke W, Vejnar Z (2002) Neoproterozoic to Early Cambrian history of an active plate margin in the Teplá-Barrandian unit-a correlation of $\mathrm{U}-\mathrm{Pb}$ isotopicdilution-TIMS ages (Bohemia, Czech Republic). Tectonophysics 352:65-85

Dörr W, Zulauf G, Gerdes A, Lahaye Y, Kowalczyk G (2015) A hidden Tonian basement in the eastern Mediterranean: age constraints from $\mathrm{U}-\mathrm{Pb}$ data of magmatic and detrital zircons of the External Hellenides (Crete and Peloponnesus). Precambrian Res 258:83-108

Dum M, Neubauer F, Liu X, Dong Y, Friedl G (2012) Middle/Upper Devonian tuffs and Eo-Alpine tectonic evolution in the central western Greywacke Zone, Austria. Austrian J Earth Sci 105:4-16

Eichhorn R, Höll R, Loth G, Kennedy A (1999) Implications of U-Pb SHRIMP zircon data on the age and evolution of the Felbertal tungsten deposit (Tauern Window, Austria). Int J Earth Sci 88:496-512

Eichhorn R, Loth G, Höll R, Finger F, Schermaier A, Kennedy A (2000) Multistage Variscan magmatism in the central Tauern Window (Austria) unveiled by U/Pb SHRIMP zircon data. Contrib Mineral Petrol 139:418-435

Eichhorn R, Loth G, Kennedy A (2001) Unravelling the pre-Variscan evolution of the Habach terrane (Tauern Window, Austria) by U-Pb SHRIMP zircon data. Contrib Mineral Petrol 142:147-162

Evuk D, Franz G, Frei D, Lucassen F (2014) The Neoproterozoic evolution of the central-eastern Bayuda Desert (Sudan). Precambrian Res 240:108-125

Finger F, Frasl G, Haunschmid B, Lettner H, von Quadt A, Schermaier A, Schindlmayr A, Steyrer HP (1993) The Zentralgneise of the Tauern Window (Eastern Alps): Insight into an intra-Alpine Variscan batholith. In: von Raumer JF, Neubauer F (eds) PreMesozoic geology in the Alps. Springer, Berlin, pp 375-391

Floyd PA, Leveridge BE (1987) Tectonic environment of the Devonian Gramscatho basin, south Cornwall: framework mode and geochemical evidence from turbiditic sandstones. J Geol Soc 144:531-542

Franz L, Romer RL (2007) Caledonian high-pressure metamorphism in the Strona-Ceneri Zone (Southern Alps of southern Switzerland and northern Italy). Swiss J Geosci 100:457-467

Frisch W, Neubauer F (1989) Pre-Alpine terranes and tectonic zoning in the Eastern Alps. Geol Soc Am Spec Pupl 230:91-99

Frisch W, Vavra G, Winkler M (1993) Evolution of the Penninic basement of the Eastern Alps. In: von Raumer JF, Neubauer F (eds) Pre-Mesozoic geology in the Alps. Springer, Berlin, pp 349-360

Frisch W, Dunkl I, Kuhlemann J (2000) Post-collisional orogen-parallel large-scale extension in the Eastern Alps. Tectonophysics 327:239-265

Garfunkel Z (2015) The relations between Gondwana and the adjacent peripheral Cadomian domain - constrains on the origin, history, and paleogeography of the peripheral domain. Gondwana Res 28:1257-1281

Garzanti E, Padoan M, Andò S, Resentini A, Vezzoli G, Lustrino M (2013) Weathering and relative durability of detrital minerals in equatorial climate: Sand petrology and geochemistry in the East African Rift. J Geol 121:547-580

Gebauer D, von Quadt A, Williams IS, Compston W, Grünenfelder M (1988) Archaean zircons in a retrograded, Caledonian eclogite of the Gotthard Massif. Swiss Bull Mineral Petrol 68:485-490

Gebauer D, Schmid R, von Quadt A, Ulmer P (1992) Oligocene, Permian and Panafrican zircon ages from rocks of the Balmuccia Peridotite and of the Lower Layered Group in the Ivrea Zone. Swiss Bull Mineral Petrol 72:113-122

Giacomini F, Braga R, Tiepolo M, Tribuzio R (2007) New constraints on the origin and age of Variscan eclogitic rocks (Ligurian Alps, Italy). Contrib Mineral Petrol 153:29-53

Griffin WL, Wang X, Jackson SE, Pearson NJ, O'Reilly SY, Xu X, Zhou X (2002) Zircon chemistry and magma mixing, SE China: in-situ analysis of Hf isotopes, Tonglu and Pingtan igneous complexes. Lithos 61:237-269

Gu XX, Liu JM, Zheng MH, Tang JX, Qi L (2002) Provenance and tectonic setting of the Proterozoic turbidites in Hunan, South China: geochemical evidence. J Sediment Res 72:393-407

Gutiérrez-Alonso G, Fernández-Suárez J, Pastor-Galán D, Johnston ST, Linnemann U, Hofmann M, Shaw J, Colmenero JR, Hernández P (2015) Significance of detrital zircons in Siluro-Devonian rocks from Iberia. J Geol Soc 172:309-322

Haditsch JG, Mostler H (1983) The Succession of ore mineralization of the Lower Austroalpine Innsbruck Quartzphyllite. In: Schneider HJ (ed) Mineral deposits of the Alps and of the Alpine Epoch in Europe. Society for Geology Applied to Mineral Deposits, vol 3. Springer, Berlin, pp 51-59

Hajná J, Žák J, Kachlík V, Dörr W, Gerdes A (2013) Neoproterozoic to early Cambrian Franciscan-type mélanges in the Teplá-Barrandian unit, Bohemian massif: evidence of modern-style accretionary processes along the Cadomian active margin of Gondwana? Precambrian Res 224:653-670

Hajná J, Žák J, Dörr W (2017) Time scales and mechanisms of growth of active margins of Gondwana: a model based on detrital zircon ages from the Neoproterozoic to Cambrian Blovice accretionary complex, Bohemian Massif. Gondwana Res 42:63-83

Hammerschmidt K, Stöckhert B (1987) A K-Ar and 40Ar/39Ar study on white micas from Brixen quartzphyllite, Southern Alps. Evidence for argon loss at low temperatures. Contrib Mineral Petrol 95:393-406

Hanžl P, Janoušek V, Soejono I, Buriánek D, Svojtka M, Hrdličková K, Erban V, Pin C (2019) The rise of the Brunovistulicum: age, geological, petrological and geochemical character of the Neoproterozoic magmatic rocks of the Central Basic Belt of the Brno Massif. Int J Earth Sci 108:1165-1199 
Hauke M, Froitzheim N, Nagel TJ, Miladinova I, Fassmer K, Fonseca ROC, Sprung P, Münker C (2019) Two high-pressure metamorphic events, Variscan and Alpine, dated by Lu-Hf in an eclogite complex of the Austroalpine nappes (Schobergruppe, Austria). Int J Earth Sci 108:1317-1331

Heinisch H, Sprenger W (1988) Mehrphasige Deformation und Pseudotachylitbildung im Gailtalkristallin und Periadriatischen Lineament zwischen Sillian und Kötschach-Mauthen (Osttirol/Kärnten, Österreich). Erlanger Geol Abh 116:41-52

Heinrichs T, Siegesmund S, Frei D, Drobe M, Schulz B (2012) Provenance signatures from whole-rock geochemistry and detrital zircon ages of metasediments from the Austroalpine basement south of the Tauern Window (Eastern Tyrol, Austria). Geo Alp 9:156-185

Herron MM (1988) Geochemical classification of terrigenous sands and shales from core or log data. J Sediment Res 58:820-829

Höck V (1993) The Habach-Formation and the Zentralgneis-a key in understanding the Palaeozoic evolution of the Tauern Window (Eastern Alps). In: von Raumer JF, Neubauer F (eds) The preMesozoic geology of the Alps. Springer, Heidelberg, pp 361-374

Hoinkes G, Thöni M (1993) Evolution of the Ötztal-Stubai, ScarlCampo and Ulten basement units. In: von Raumer JF, Neubauer F (eds) The pre-Mesozoic geology of the Alps. Springer, Heidelberg, pp 485-494

Hoinkes G, Koller F, Rantitsch G, Dachs E, Höck V, Neubauer F, Schuster R (1999) Alpine metamorphism of the Eastern Alps. Swiss Bull Mineral Petrol 79:155-181

Höll R, Maucher A (1967) Genese und Alter der Scheelit-MagnesitLagerstätte Tux in Tirol. Bayrische Akademie der Wissenschaften Sitzungsberichte, pp 1-11

Ivan P, Méres S (2015) Geochemistry of amphibolites and related graphitic gneisses from the Suchý and Malá Magura Mountains (central Western Carpathians) - evidence for relics of the Variscan ophiolite complex. Geol Carpath 66:347-360

Jansen U (2012) Die Welt des frühen Devons aus der Sicht der Brachiopodenforschung. Natur Forschung Museum 142:44-51

Jansen U (2016) Brachiopod faunas, facies and biostratigraphy of the Pridolian to lower Eifelian succession in the Rhenish Massif (Rheinisches Schiefergebirge, Germany). In: Becker RT, Königshof P, Brett CE (eds) Devonian climate, sea level and evolutionary events, vol 423. Geological Society, London, Special Publications, pp 45-122

Kabon H, Schönlaub HP (2019) Das geologische Geheimnis der Hochwipfel Formation in den Karnischen Alpen. Naturwissenschaftlicher Verein für Kärnten

Kebede T, Klötzli U, Kosler J, Skiöld T (2005) Understanding the pre-Variscan and Variscan basement components of the central Tauern Window, Eastern Alps (Austria): constraints from single zircon U-Pb geochronology. Int J Earth Sci 94:336-353

Klötzli-Chowanetz E, Klötzli U, Koller F (1997) Lower Ordovician migmatization in the Ötztal crystalline basement (Eastern Alps, Austria): linking $\mathrm{U}-\mathrm{Pb}$ and $\mathrm{Pb}-\mathrm{Pb}$ dating with zircon morphology. Schweiz Miner Petrog Mitt 77:315-324

Klötzli-Chowanetz E, Klötzli U, Skiöld T (2001) Cambrian migmatisation and Ordovician tonalitic intrusion-Klopaier area, Ötztal crystalline complex, Eastern Alps. Mitt Österr Mineral Ges 146:133-134

Korikovsky SP, Putiš M, Kotov AB, Sal'nikova EB, Kovach VP (1998) High-pressure metamorphism of phengite gneisses in the lower Austro-Alpine Nappe Unit, Eastern Alps: mineral equilibria, P-T parameters, and age. Petrology 6:655-672

Košler J, Konopásek J, Sláma J, Vrána S (2014) U-Pb zircon provenance of Moldanubian metasediments in the Bohemian Massif. J Geol Soc 171:83-95
Krainer K, Vachard D (2015) Late Viséan (MFZ14) foraminifers and algae from the Kirchbach Limestone (Carnic Alps, Austria) and geological implications. Facies 61:418

Krenn E, Schulz B, Finger F (2012) Three generations of monazite in Austroalpine basement rocks to the south of the Tauern Window: evidence for Variscan, Permian and Eo-Alpine metamorphic events. Swiss J Geosci 105:343-360

Kroner U, Romer RL (2013) Two plates-many subduction zones: the Variscan orogeny reconsidered. Gondwana Res 24:298-329

Kunz BE, Manzotti P, von Niederhäusern B, Engi M, Darling JR, Giuntoli F, Lanari P (2018) Permian high-temperature metamorphism in the Western Alps (NW Italy). Int J Earth Sci 107:203-229

Küster D, Liégeois J-P, Matukov D, Sergeev S, Lucassen F (2008) Zircon geochronology and $\mathrm{Sr}, \mathrm{Nd}, \mathrm{Pb}$ isotope geochemistry of granitoids from Bayuda Desert and Sabaloka (Sudan): Evidence of a Bayudian event (920-900 Ma) preceding the Pan-African orogenic cycle (860-590 Ma) at the eastern boundary of the Saharan Metacraton. Precambrian Res 164:16-39

Lammerer B, Gebrande H, Lüschen E, Vesela P (2008) A crustal-scale cross-section through the Tauern Window (eastern Alps) from geophysical and geological data. In: Siegesmund S, Fügenschuh B, Froitzheim N (ed) Tectonic aspects of the Alpine-DinarideCarpathian system, vol 296. Geological Society, London, Special Publications, pp 219-229

Läufer A, Hubich D, Loeschke J (2001) Variscan geodynamic evolution of the Carnic Alps (Austria/Italy). Int J Earth Sci 90:855-870

Lerchbaumer L, Kloetzli U, Pestal G (2010) Schists and amphibolites of the Kleinelendtal (Ankogel-Hochalm-Gruppe/Hohe Tauern, Austria)/new insights on the Variscan basement in the Eastern Tauern Window. Austrian J Earth Sci 103:138-152

Liati A, Gebauer D, Fanning CM (2009) Geochronological evolution of HP metamorphic rocks of the Adula nappe, Central Alps, in preAlpine and Alpine subduction cycles. J Geol Soc 166:797-810

Liégeois J-P, Stern RJ (2010) Sr-Nd isotopes and geochemistry of granite-gneiss complexes from the Meatiq and Hafafit domes, Eastern Desert, Egypt: No evidence for pre-Neoproterozoic crust. J Afr Earth Sci 57:31-40

Liégeois J-P, Abdelsalam MG, Ennih N, Ouabadi A (2013) Metacraton: Nature, genesis and behavior. Gondwana Res 23:220-237

Linnemann U, Gerdes A, Drost K, Buschmann B (2007) The continuum between Cadomian orogenesis and opening of the Rheic Ocean: constraints from LA-ICP-MS U-Pb zircon dating and analysis of plate-tectonic setting (Saxo-Thuringian zone, northeastern Bohemian Massif, Germany). Geological Society, American Special Publications, vol 423, pp 61-96

Linnemann U, Gerdes A, Hofmann M, Marko L (2014) The Cadomian Orogen: Neoproterozoic to Early Cambrian crustal growth and orogenic zoning along the periphery of the West African Craton-constraints from U-Pb zircon ages and $\mathrm{Hf}$ isotopes (Schwarzburg Antiform, Germany). Precambrian Res 244:236-278

Liu Y, Genser J, Handler R, Friedl G, Neubauer F (2001) ${ }^{40} \mathrm{Ar} /{ }^{39} \mathrm{Ar}$ muscovite ages from the Penninic-Austroalpine plate boundary, Eastern Alps. Tectonics 20:526-547

Loeschke J, Heinisch H (1993) Palaeozoic volcanism of the Eastern Alps and its palaeotectonic significance. In: von Raumer JF, Neubauer F (eds) Pre-Mesozoic geology in the Alps. Springer, Berlin, pp 441-455

Mader D, Neubauer F, Handler R (2007) ${ }^{40} \mathrm{Ar} /{ }^{39} \mathrm{Ar}$ dating of detrital white mica of Upper Paleozoic sandstones in the Carnic Alps (Austria): implications for provenance and tectonic setting. Geol Carpath 58:133-144

Maino M, Gaggero L, Langone A, Seno S, Fanning M (2019) CambroSilurian magmatisms at the northern Gondwana margin (Penninic basement of the Ligurian Alps). Geosci Front 10:315-330 
Mandl M, Kurz W, Hauzenberger C, Fritz H, Klötzli U, Schuster R (2018) Pre-Alpine evolution of the Seckau Complex (Austroalpine basement/Eastern Alps): Constraints from in-situ LA-ICPMS U-Pb zircon geochronology. Lithos 296:412-430

Mazzoli C, Sassi FP (1992) New chemical data on the Upper Ordovician acidic plutonism in the Austrides of the Eastern Alps. In: Carmignani L, Sassi FP (ed) Contributions to the geology of Italy with special regard to the Palaeozoic basements. IGCP international geological correlation program 276 newsletter, vol 5, pp 263-277

McLennan SM (2001) Relationships between the trace element composition of sedimentary rocks and upper continental crust. Geochem Geophys Geosyst 2:1021

McLennan SM, Hemming S, McDaniel DK, Hanson GN (1993) Geochemical approaches to sedimentation, provenance, and tectonics. Geological Society American Special Publications, vol 284, pp 21-21

Meinhold G, Morton AC, Fanning CM, Frei D, Howard JP, Phillips RJ, Strogen D, Whitham AG (2011) Evidence from detrital zircons for recycling of Mesoproterozoic and Neoproterozoic crust recorded in Paleozoic and Mesozoic sandstones of southern Libya. Earth Planet Sci Lett 312:164-175

Meinhold G, Morton AC, Avigad D (2013) New insights into periGondwana paleogeography and the Gondwana super-fan system from detrital zircon U-Pb ages. Gondwana Res 23:661-665

Meli S (2004) Rb-Sr and ${ }^{40} \mathrm{Ar} /{ }^{39} \mathrm{Ar}$ age constraints on the Variscan metamorphism recorded by Ordovician acidic metavolcanic rocks in the Eastern Southalpine basement. Rendiconti Lincei 9:205-223

Meli S, Klötzli US (2001) Evidence for Lower Paleozoic magmatism in the Eastern Southalpine basement: zircon geochronology from Comelico porphyroids. Schweiz Miner Petrog Mitt 81:147-157

Miller C, Thöni M (1995) Origin of eclogites from the Austroalpine Ötztal basement (Tirol, Austria): geochemistry and Sm-Nd vs $\mathrm{Rb}-\mathrm{Sr}$ isotope systematics. Chem Geol 122:199-225

Mogessie A, Purtscheller F (1986) Polymetamorphism of the OetztalStubai basement complex based on amphibolite petrology. Jb Geol B A Wien 129:69-91

Mogessie A, Purtscheller F, Tessadri R (1985) Geochemistry of amphibolites from the Ötztal-Stubai Complex (Northern Tyrol, Austria). Chem Geol 51:103-113

Moghadam HS, Li XH, Santos JF, Stern RJ, Griffin WL, Ghorbani G, Sarebani N (2017) Neoproterozoic magmatic flare-up along the N. margin of Gondwana: the Taknar complex, NE Iran. Earth Planet Sci Lett 474:83-96

Moghadam HS, Li QL, Griffin WL, Stern RJ, Ishizuka O, Henry H, Lucci F, O'Reilly SY, Ghorbani G (2019) Repeated magmatic buildup and deep "hot zones" in continental evolution: the Cadomian crust of Iran. Earth Planet Sci Lett 531:115989

Müller B, Klötzli US, Flisch M (1995) U-Pb and Pb-Pb zircon dating of the older orthogneiss suite in the Silvretta nappe, eastern Alps: Cadomian magmatism in the upper Austro-Alpine realm. Geol Rundsch 84:457-465

Müller RD, Cannon J, Qin X, Watson RJ, Gurnis M, Williams S, Pfaffelmoser T, Seton M, Russell SHJ, Zahirovic S (2018) GPlates: building a virtual Earth through deep time. Geochem Geophys Geosyst 19:2243-2261

Murphy JB, Gutiérrez-Alonso G, Nance RD, Fernández-Suárez J, Keppie JD, Quesada C, Strachan RA, Dostal J (2006) Origin of the Rheic Ocean: rifting along a Neoproterozoic suture? Geology 34:325-328

Murphy JB, Pisarevsky S, Nance RD (2013) Potential geodynamic relationships between the development of peripheral orogens along the northern margin of Gondwana and the amalgamation of West Gondwana. Mineral Petrol 107:635-650
Nance RD, Gutiérrez-Alonso G, Keppie JD, Linnemann U, Murphy JB, Quesada C, Strachan RA, Woodcock NH (2010) Evolution of the Rheic Ocean. Gondwana Res 17:194-222

Nance RD, Gutiérrez-Alonso G, Keppie JD, Linnemann U, Murphy JB, Quesada C, Strachan RA, Woodcock NH (2012) A brief history of the Rheic Ocean. Geosci Front 3:125-135

Nesbitt HW, Young GM (1982) Early Proterozoic climates and plate motions inferred from major element chemistry of lutites. Nature 299:715-717

Neubauer F (2002) Evolution of late Neoproterozoic to early Palaeozoic tectonic elements in Central and Southeast European Alpine mountain belts: review and synthesis. Tectonophysics 352:87-103

Neubauer F, Handler R (2000) Variscan orogeny in the Eastern Alps and Bohemian Massif: How do these units correlate? Mitt Österr Geolog Gesell 92:35-59

Neubauer F, Sassi FP (1993) The Austro-Alpine quartzphyllites and related Palaeozoic formations. In: von Raumer JF, Neubauer F (eds) The pre-Mesozoic geology of the Alps. Springer, Heidelberg, pp 423-439

Neubauer F, Hoinkes G, Sassi FP (1999) Pre-Alpine metamorphism of the Eastern Alps. Swiss Bull Mineral Petrol 79:41-62

Neubauer F, Klötzli US, Poscheschnik P (2001) Cadomian magmatism in the Alps recorded in Late Ordovician sandstones of the Carnic Alps: preliminary results from zircon $\mathrm{Pb} / \mathrm{Pb}$ evaporation dating. Schweiz Mineral Petrogr Mitt 81:175-179

Neubauer F, Liu Y, Chang R, Yuan S, Yu S, Genser J, Liu B, Guan Q (2020) The Wechsel Gneiss Complex of Eastern Alps: an Ediacaran to Cambrian continental arc and its Early Proterozoic hinterland. Swiss J Geosci 113:1-23

Ohta T, Arai H (2007) Statistical empirical index of chemical weathering in igneous rocks: a new tool for evaluating the degree of weathering. Chem Geol 240:280-297

Oriolo S, Oyhantçabal P, Wemmer K, Siegesmund S (2017) Contemporaneous assembly of Western Gondwana and final Rodinia break-up: implications for the supercontinent cycle. Geosci Front 8:1431-1445

Oriolo S, Schulz B, Geuna S, González PD, Otamendi JE, Sláma J, Druguet E, Siegesmund S (2021) Early Paleozoic accretionary orogens along the Western Gondwana margin. Geosci Front 12:109-130. https://doi.org/10.1016/j.gsf.2020.07.001

Parker A (1970) An index of weathering for silicate rocks. Geol Mag 107:501-504

Pastor-Galán D, Gutiérrez-Alonso G, Murphy JB, Fernández-Suárez J, Hofmann M, Linnemann U (2013) Provenance analysis of the Paleozoic sequences of the northern Gondwana margin in NW Iberia: passive margin to Variscan collision and orocline development. Gondwana Res 23:1089-1103

Peucat JJ (1986) Behaviour of Rb-Sr whole rock and U-Pb zircon systems during partial melting as shown in migmatitic gneisses from the St Malo Massif, NE Brittany, France. J Geol Soc 143:875-885

Piber A, Tropper P (2005) Thermobarometry of the Innsbruck Quartzphyllite and implications for its polymetamorphic nature. Geophys Res Abs 7:04330

Pondrelli M, Corradini C, Simonetto L, Corriga MG, Kido E, Mossoni A, Spalletta C, Suttner TJ, Carta N (2015) Depositional evolution of a lower Paleozoic portion of the Southalpine domain: the Mt. Pizzul area (Carnic Alps, Italy). Int J Earth Sci 104:147-178

Purtscheller F (1978) Ötztaler und Stubaier Alpen. Sammlung Geologischer Führer 53, 2nd edition. Stuttgart, Gebrüder Bornträger

Rantitsch G (1997) Thermal history of the Carnic Alps (Southern Alps, Austria) and its palaeogeographic implications. Tectonophysics 272:213-232 
Ratschbacher L, Frisch W (1993) Palinspastic reconstruction of the pre-Triassic basement units in the Alps: the Eastern Alps. In: von Raumer JF, Neubauer F (eds) Pre-Mesozoic geology in the Alps. Springer, Berlin, pp 41-51

Ratschbacher L, Frisch W, Linzer HG, Merle O (1991) Lateral extrusion in the Eastern Alps, Part 2: Structural analysis. Tectonics 10:257-271

Reitz E, Höll R (1990) Biostratigraphischer Nachweis von Unterordovizium in der Innsbrucker Quarzphyllitserie (Ostalpen). Jb Geol B A Wien 133:603-610

Rockenschaub M, Kolenprat B, Nowotny A (2003) Innsbrucker Quarzphyllitkomplex, Tarntaler Mesozoikum, Patscherkofelkristallin. Geologische Bundesanstalt-Arbeitstagung 2003, Blatt 148 Brenner, pp 41-58

Rode S, Rösel D, Schulz B (2012) Constraints on the Variscan P-T evolution by EMP Th-U-Pb monazite dating in the polymetamorphic Austroalpine Oetztal-Stubai basement (Eastern Alps). Z Dtsch Ges Geowiss 163:43-67

Romer RL, Kroner U (2019) First direct evidence for a contiguous Gondwana shelf to the south of the Rheic Ocean. Geology 47:767-770

Rubatto D, Schaltegger U, Lombardo D, Colombo F, Compagnoni R (2001) Complex Paleozoic magmatic and metamorphic evolution in the Argentera massif (Western Alps), resolved with $\mathrm{U}-\mathrm{Pb}$ dating. Schweiz Miner Petrog Mitt 81:213-228

Rubatto D, Ferrando S, Compagnoni R, Lombardo B (2010) Carboniferous high-pressure metamorphism of Ordovician protoliths in the Argentera Massif (Italy), Southern European Variscan belt. Lithos 116:65-76

Sassi FP, Spiess R (1993) The South-Alpine metamorphic basement in the Eastern Alps. In: von Raumer JF, Neubauer F (eds) PreMesozoic geology in the Alps. Springer, Berlin, pp 599-607

Sassi FP, Kalvacheva S, Zanferrari A (1984) New data on the age of deposition of the South-Alpine phyllitic basement in the Eastern Alps. N Jb Geol Paläont Mh 12:741-775

Sassi FP, Zanferrari A, Zirpoli G (1987) The Caledonian event in the Eastern Alps. In: Flügel HW, Sassi FP, Grecula P (eds) Pre-Variscan and Variscan events in the Alpin-Mediterranean Mountain Belts, Bratislava Alfa Publishers, pp 431-434

Schaltegger U (1993) The evolution of the polymetamorphic basement in the Central Alps unravelled by precise $\mathrm{U}-\mathrm{Pb}$ zircon dating. Contrib Mineral Petrol 113:466-478

Schaltegger U, Nägler T, Corfu F, Maggetti M, Galetti G, Stosch HG (1997) A Cambrian island arc in the Silvretta nappe: Constraints from geochemistry and geochronology. Schweiz Miner Petrog Mitt 77:337-350

Schaltegger U, Abrecht J, Corfu F (2003) The Ordovician orogeny in the Alpine basement: constraints from geochronology and geochemistry in the Aar Massif (Central Alps). Schweiz Miner Petrog Mitt 83:183-239

Scheiber T, Berndt J, Mezger K, Pfiffner OA (2014) Precambrian to Paleozoic zircon record in the Siviez-Mischabel basement (western Swiss Alps). Swiss J Geosci 107:49-64

Schmid SM, Fügenschuh B, Kissling E, Schuster R (2004) Tectonic map and overall architecture of the Alpine orogeny. Eclogae Geol Helv 97:93-117

Schmid SM, Scharf A, Handy MR, Rosenberg CL (2013) The Tauern Window (Eastern Alps, Austria): a new tectonic map, with crosssections and a tectonometamorphic synthesis. Swiss J Geosci 106:1-32

Schmid SM, Fügenschuh B, Kounov A, Maţenco L, Nievergelt P, Oberhänsli R, Pleuger S, Schuster R, Tomljenović B, Ustaszewski K, van Hinsbergen DJJ (2020) Tectonic units of the Alpine collision zone between Eastern Alps and western Turkey. Gondwana Res 78:308-374
Scholl DW, von Huene R (2009) Implications of estimated magmatic additions and recycling losses at the subduction zones of accretionary (non-collisional) and collisional (suturing) orogens. In: Cawood PA, Kröner A (ed) Earth accretionary systems in space and time. Geological Society, London, Special Publications, vol 318, pp 105-125

Schönlaub HP (1985) Das Paläozoikum der Karnischen Alpen. In: Schönlaub HP (ed) Arbeitstagung der Geologischen Bundesanstalt 1985 Kötschach-Mauthen, Gailtal. Geologische Bundesanstalt, Vienna, pp 34-52

Schönlaub HP, Heinisch H (1993) The classic fossiliferous Paleozoic units of the Eastern Alps. In: von Raumer JF, Neubauer F (eds) Pre-Mesozoic geology in the Alps. Springer, Berlin, pp 395-422

Schönlaub HP, Histon K (2000) The Palaeozoic evolution of the Southern Alps. Mitt Österr Geol Ges 92:15-34

Schulz B (2008) Basement of the Alps. In: McCann T (ed) Geology of Central Europe, vol 1. Precambrian and Paleozoic. Geological Society, London, pp 79-83

Schulz B, Bombach K (2003) Single zircon $\mathrm{Pb}-\mathrm{Pb}$ geochronology of the early-Palaeozoic magmatic evolution in the Austroalpine basement to the south of the Tauern Window. Jahrb Geol BA 143:303-321

Schulz B, von Raumer JF (2011) Discovery of Ordovician-Silurian metamorphic monazite in garnet metapelites of the Alpine External Aiguilles Rouges Massif. Swiss J Geosci 104:67-79

Schulz B, Nollau G, Heinisch H, Godizart G (1993) Austro-Alpine Basement Complex to the south of the Tauern Window. In: von Raumer JF, Neubauer F (eds) Pre-Mesozoic geology in the Alps. Springer, Berlin, pp 496-514

Schulz B, Bombach K, Pawlig S, Brätz H (2004) Neoproterozoic to early-Palaeozoic magmatic evolution in the Gondwana-derived Austroalpine basement to the south of the Tauern Window (Eastern Alps). Int J Earth Sci 93:824-843

Schulz B, Brätz H, Klemd R (2006) Host rock compositional controls on zircon trace-element signatures in metabasites from the Austroalpine basement. Geochim Cosmochim Acta 70:697-710

Schulz B, Steenken A, Siegesmund S (2008) Geodynamic evolution of an Alpine terrane- the Austroalpine basement to the south of the Tauern window as a part of the Adriatic Plate (eastern Alps). In: Siegesmund S, Fügenschuh B, Froitzheim N (eds) Tectonic aspects of the Alpine-Dinaride-Carpathian System. Geological Society, London, Special Publications, vol 298, pp 5-44

Schulz B, Krause J, Zimmermann R (2019) Electron microprobe petrochronology of monazite-bearing garnet micaschists in the Oetztal-Stubai Complex (Alpeiner Valley, Stubai). Swiss J Geosci 112:597-617

Schulz B, Sandmann D, Gilbricht S (2020) SEM-based automated mineralogy and its application in geo-and material sciences. Minerals 10:1004

Schuster R, Egger H, Krenmayr HG, Linner M, Mandl GW, Matura A, Pascher G, Pestal G, Pistotnik J, Rockenschaub M, Schnabel W (2015) Geologische Übersichtskarte 1:1.500.000 der Republik Österreich. Geologische Bundesanstalt, Wien

Schweigl J (1995) Neue geochronologische und isotopengeologische Daten zur voralpidischen Entwicklungsgeschichte im Ötztalkristallin (Ostalpen). Jb Geol BA 138:131-149

Scotese CR (2016) PALEOMAP PaleoAtlas for GPlates and the PaleoData Plotter Program. PALEOMAP Project. https://doi.org/10. 13140/RG2.2.34367.00166

Siegesmund S, Heinrichs T, Romer RL, Doman D (2007) Age constraints on the evolution of the Austroalpine basement to the south of the Tauern Window. Int J Earth Sci 96:415-432

Siegesmund S, Oriolo S, Heinrichs T, Basei MAS, Nolte N, Hüttenrauch F, Schulz B (2018) Provenance of Austroalpine basement metasediments: tightening up Early Palaeozoic connections 
between peri-Gondwanan domains of central Europe and Northern Africa. Int J Earth Sci 107:2293-2315

Söderlund U, Patchett PJ, Vervoort JD, Isachsen CE (2004) The ${ }^{176} \mathrm{Lu}$ decay constant determined by $\mathrm{Lu}-\mathrm{Hf}$ and $\mathrm{U}-\mathrm{Pb}$ isotope systematics of Precambrian mafic intrusions. Earth Planet Sci Lett 219:311-324

Söllner F, Miller H, Höll R (1997) Alter und Genese rhyodazitischer Metavulkanite ("Porphyroide") der Nördlichen Grauwackenzone und der Karnischen Alpen (Österreich): Ergebnisse von U-PbZirkondatierungen. Z Deutsch Geol Ges 148:499-522

Spalletta C, Venturini C, Schönlaub H-P, Pondrelli M (2015) Hochwipfel formation. In: Corradini C, Suttner TJ (ed) The Pre-Variscan sequence of the Carnic Alps (Austria and Italy), vol 69. Abh Geol Bundesantsalt, pp 151-154

Sprenger W, Heinisch H (1992) Late Oligocene to recent brittle transpressive deformation along the Periadriatic Lineament in the Lesach Valley (Eastern Alps): remote sensing and paleo-stress analysis. Annales Tectonicae 6:134-149

Stampfli GM (2000) Tethyan oceans. In: Bozkurt E, Winchester JA, Piper JDA (ed) Tectonics and magmatism in Turkey and the surrounding area. Geological society, London, Special Publications, vol 173, pp 1-23

Stampfli GM, von Raumer JF, Borel GD (2002) Paleozoic evolution of pre-Variscan terranes: from Gondwana to the Variscan collision. Geological Society American Special Publications, vol 364, pp 263-280

Stampfli GM, von Raumer J, Wilhem C (2011) The distribution of Gondwana derived terranes in the early Paleozoic. In: GutiérrezMarco JC, Rábano I, García-Bellido D (eds) The Ordovician of the world. Cuadernos del Museo Geominero, Instituto Geológico y Minero de España, Madrid, 14, pp 567-574

Stephan T, Kroner U, Romer RL, Rösel D (2019a) From a bipartite Gondwana shelf to an arcuate Variscan belt: The early Paleozoic evolution of northern Peri-Gondwana. Earth Sci Rev 192:491-512

Stephan T, Kroner U, Romer RL (2019b) The pre-orogenic detrital zircon record of the Peri-Gondwanan crust. Geol Mag 156:281-307

Stern CR (2011) Subduction erosion: rates, mechanisms, and its role in arc magmatism and the evolution of the continental crust and mantle. Gondwana Res 20:284-308

Stern RJ, Scholl DW (2010) Yin and yang of continental crust creation and destruction by plate tectonic processes. Int Geol Rev 52:1-31

Taylor SR, McLennan SM (1995) The geochemical evolution of the continental crust. Rev Geophys 33:241-265

Thöni M (1981) Degree and evolution of the Alpine metamorphism in the Austroalpine Unit W of Hohe Tauern in the light of K/ $\mathrm{Ar}$ and $\mathrm{Rb} / \mathrm{Sr}$ Age Determinations in Micas. Jb Geol BA Wien 124:111-174

Thöni M (1983) The climax of the early Alpine metamorphism in the Austroalpine thrust sheet. Mem Sci Geol Padova 36:211-238

Thöni M (1999) A review of geochronological data from the Eastern Alps. Swiss Bull Min Petrol 79:209-230

Thöny WF, Tropper P, Schennach F, Krenn E, Finger F, Kaindl R, Franz B, Hoinkes G (2008) The metamorphic evolution of migmatites from the Ötztal Complex (Tyrol, Austria) and constraints on the timing of the pre-Variscan high-T event in the Eastern Alps. Swiss J Geosci 101:111-126

Tropper P, Hoinkes G (1996) Geothermobarometry of $\mathrm{Al}_{2} \mathrm{SiO}_{5}$-bearing metapelites in the western Austroalpine Ötztal-basement. Mineral Petrol 58:145-170

Tropper P, Recheis A (2003) Garnet zoning as a window into the metamorphic evolution of a crystalline complex: the northern and central Austroalpine Ötztal-Complex as a polymorphic example. Mitt Österr Geol Ges 94:27-53

Tropper P, Finger F, Krenn E, Klötzli U, Piber A, Gangl S (2016) The Kellerjoch Gneiss (Tyrol, Eastern Alps): an Ordovician pluton with A-type affinity in the crystalline basement nappes north of the Tauern Window. Austrian J Earth Sci 109:178-188

Tumiati S, Thöni M, Nimis P, Martin S, Mair V (2003) Mantle-crust interactions during Variscan subduction in the Eastern Alps (Nonsberg-Ulten zone): geochronology and new petrological constraints. Earth Planet Sci Lett 210:509-526

Verma SP, Armstrong-Altrin JS (2013) New multi-dimensional diagrams for tectonic discrimination of siliciclastic sediments and their application to Precambrian basins. Chem Geol 355:117-133

Vermeesch P (2012) On the visualization of detrital age distributions. Chem Geol 312-313:190-194

Veselá P, Lammerer B, Wetzel A, Söllner F, Gerdes A (2008) PostVariscan to Early Alpine sedimentary basins in the Tauern Window (eastern Alps In: Siegesmund S, Fügenschuh B, Froitzheim $\mathrm{N}$ (ed) Tectonic aspects of the Alpine-Dinaride-Carpathian System. Geological Society, London, Special Publications, vol 298, pp 83-100

Veselá P, Söllner F, Finger F, Gerdes A (2010) Magmato-sedimentary Carboniferous to Jurassic evolution of the western Tauern window, Eastern Alps (constraints from U-Pb zircon dating and geochemistry). Int J Earth Sci 100:993-1027

von Quadt A (1992) U-Pb zircon and Sm-Nd geochronology of mafic and ultramafic rocks from the central part of the Tauern Window (Eastern Alps). Contrib Mineral Petrol 110:57-67

von Quadt A, Günther D, Frischknecht R, Zimmermann R, Franz G (1997) The evolution of pre-Variscan eclogites of the Tauern Window (Eastern Alps): a Sm/Nd-, conventional and Laser ICPMS zircon U-Pb study. Schweiz Miner Petrog Mitt 77:265-279

von Raumer JF, Stampfli GM, Bussy F (2003) Gondwana-derived microcontinents - the constituents of the Variscan and Alpine collisional orogens. Tectonophysics 365:7-22

von Raumer JF, Bussy F, Stampfli GM (2009) The Variscan evolution in the External massifs of the Alps and place in their Variscan framework. C R Geosci 341:239-252

von Raumer JF, Bussy F, Schaltegger U, Schulz B, Stampfli GM (2013) Pre-Mesozoic Alpine basements-their place in the European Paleozoic framework. Geol Soc Am Bull 125:89-108

von Raumer JF, Stampfli GM, Arenas R, Martínez SS (2015) Ediacaran to Cambrian oceanic rocks of the Gondwana margin and their tectonic interpretation. Int J Earth Sci 104:1107-1121

Wyhlidal S, Thöny WF, Tropper P, Klötzli U, Mair V (2010) U-Pb geochronology of detrital zircons from a contact metamorphic Brixen Quartzphyllite (South-Tyrol, Italy): evidence for a complex pre-Variscan evolution of the Southalpine basement. Swiss J Geosci 103:273-281

Žák J, Sláma J (2018) How far did the Cadomian 'terranes' travel from Gondwana during early Palaeozoic? A critical reappraisal based on detrital zircon geochronology. Int Geol Rev 60:319-338

Zlatkin O, Avigad D, Gerdes A (2014) Peri-Amazonian provenance of the Proto-Pelagonian basement (Greece), from zircon U$\mathrm{Pb}$ geochronology and $\mathrm{Lu}-\mathrm{Hf}$ isotopic geochemistry. Lithos 184:379-392

Zlatkin O, Avigad D, Gerdes A (2017) The Pelagonian terrane of Greece in the peri-Gondwanan mosaic of the Eastern Mediterranean: implications for the geological evolution of Avalonia. Precambr Res 290:163-183

Zulauf G, Schitter F, Riegler G, Finger F, Fiala J, Vejnar Z (1999) Age constraints on the Cadomian evolution of the Teplá Barrandian unit (Bohemian Massif) through electron microprobe dating of metamorphic monazite. Z Dtsch Geol Ges 150:627-639

Zurbriggen R (2015) Ordovician orogeny in the Alps: a reappraisal. Int J Earth Sci 104:335-350

Zurbriggen R (2017) The Cenerian orogeny (early Paleozoic) from the perspective of the Alpine region. Int J Earth Sci 106:517-529 